\title{
DÜBLIN
}

Technological University Dublin

ARROW@TU Dublin

\section{Chemical Modifications of Lipids and Proteins by Nonthermal Food Processing Technologies}

\author{
Juan M. Pérez-Andrés \\ Technological University Dublin, juanmanuel.perezandres@tudublin.ie \\ Clémentine Charoux \\ Teagasc Food Research Centre \\ Patrick J. Cullen \\ Technological University Dublin, patrick.j.cullen@tudublin.ie
}

See next page for additional authors

Follow this and additional works at: https://arrow.tudublin.ie/schfsehart

Part of the Chemistry Commons, and the Food Chemistry Commons

\section{Recommended Citation \\ This Article is brought to you for free and open access by the School of Food Science and Environmental Health at ARROW@TU Dublin. It has been accepted for inclusion in Articles by an authorized administrator of ARROW@TU Dublin. For more information, please contact arrow.admin@tudublin.ie, aisling.coyne@tudublin.ie, gerard.connolly@tudublin.ie.}

Juan M. Pérez-Andrés, Clémentine M. G. Charoux, P. J. Cullen, and Brijesh K. Tiwari Journal of Agricultural and Food Chemistry 201866 (20), 5041-5054 DOI: 10.1021/acs.jafc.7b06055

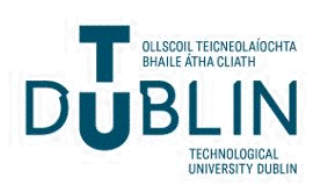


Authors

Juan M. Pérez-Andrés, Clémentine Charoux, Patrick J. Cullen, and Brijesh K. Tiwari

This article is available at ARROW@TU Dublin: https://arrow.tudublin.ie/schfsehart/451 


\title{
Chemical Modifications of Lipids and Proteins by Nonthermal Food Processing Technologies
}

\author{
Juan M. Pérez-Andrés, ${ }^{\dagger \neq}$ Clémentine M. G. Charoux, ${ }^{\dagger, \S}$ P. J. Cullen, ${ }^{\ddagger}, \|$ and Brijesh K. Tiwari, ${ }^{* \dagger \odot}$ \\ ${ }^{\dagger}$ Food Chemistry and Technology, Teagasc Food Research Centre, Dublin 3, Ireland \\ ${ }^{\ddagger}$ BioPlasma Research Group, School of Food Science and Environmental Health, Dublin Institute of Technology, Cathal Brugha \\ Street, Dublin 1, Ireland \\ ${ }^{\S}$ School of Biosystems and Food Engineering, University College Dublin, Dublin 4, Ireland \\ "Department of Chemical and Environmental Engineering, University of Nottingham, Nottingham, NG7 2RD, U.K.
}

ABSTRACT: A range of nonthermal techniques have demonstrated process efficacy in ensuring product safety, extension of shelf life, and in general a retention of key quality attributes. However, various physical, chemical and biochemical effects of nonthermal techniques on macro and micro nutrients are evident, leading to both desirable and undesirable changes in food products. The objective of this review is to outline the effects of nonthermal techniques on food chemistry and the associated degradation mechanisms with the treatment of foods. Oxidation is one of the key mechanisms responsible for undesirable effects induced by nonthermal techniques. Degradation of key macromolecules largely depends on the processing conditions employed. Various extrinsic and intrinsic control parameters of high-pressure processing, pulsed electric field, ultrasound processing, and cold atmospheric plasma on chemistry of processed food are outlined. Proposed mechanisms and associated degradation of macromolecules, i.e., proteins, lipids, and bioactive molecules resulting in food quality changes are also discussed.

KEYWORDS: lipid oxidation, protein oxidation, high-pressure processing, pulsed electric field, ultrasound and cold plasma processing

\section{INTRODUCTION}

Classical thermal technologies are based on the use of heat to extend food shelf life and ensure product safety by inactivating spoilage enzymes and microorganisms. Techniques such as thermal sterilization and pasteurization are a cornerstone of food processing. In these cases, heat is generated by electrical resistance or combustion which is transferred to the product. These technologies require relatively high energy which results in high costs and consequently are not environmental friendly. Use of novel thermal technologies are rapidly emerging, offering greater efficiency and process control, including, ohmic heating and dielectric heating, which includes radio frequency (rf) and microwave heating (MW). Such techniques have demonstrated process efficacy in ensuring product safety, extension of shelf life and good retention of critical quality attributes along with providing a more sustainable food processing sector. ${ }^{1,2}$ The main difference from the traditional techniques is that the heat is generated directly inside the product, allowing a reduction of heat/energy loss, leading to lower costs and greener solutions. ${ }^{3}$ However, when a product is heated, even to moderate temperatures, flavors, essential nutrients, and vitamins can be modified. ${ }^{4,5}$ Alternatives to classical and novel thermal techniques are a range of technologies collectively called "nonthermal technologies". These technologies are effective at ambient or sublethal temperatures, thereby minimizing negative thermal consequences. High-pressure processing, pulsed electric field, cold plasma, and ultrasound processing are the leading nonthermal technologies. $^{6,7}$ They can inactivate both pathogenic and spoilage microorganisms associated with food, resulting in extensions of shelf life with microbiological safety profiles. The potential and adoption of such nonthermal treatments has been further expanded by regulatory agencies increasingly acknowledging their demonstrated efficacies. ${ }^{8}$ Of note here is the expansion of the definition of pasteurization beyond solely a thermal treatment by the NACMCF (the U.S. National Advisory Committee on Microbiological Criteria for Foods Adopted August 27, 2004 Washington, DC) to include any treatments which can "reduce the most resistant microorganism(s) of public health significance to a level that is not likely to present a public health risk under normal conditions of distribution and storage". Apart from their use as a single intervention technology, several studies have shown that such technologies used along with conventional techniques can ensure food safety with limited impacts on the food quality. For instance, ultrasound-assisted hot air drying can reduce the drying time of strawberries in the range of $13-44 \%$, thus moderating the damage on food quality. ${ }^{9}$ In the context of sterilization, using high pressure together with mild or high temperatures treatments to inactivate bacterial spores have also shown benefits. ${ }^{10}$ Comparably, a combination of nonthermal technologies is also proposed (hurdle approach), to achieve effective microbial inactivation while mitigating negative effects on product quality. In order to meet growing consumer demand for high quality food, it is necessary to understand the mechanisms of action driving these potential technologies and the response of food chemistry to such processes. Applications

Received: December 28, 2017

Revised: April 5, 2018

Accepted: April 19, 2018

Published: April 19, 2018 
of novel thermal and nonthermal technologies have been reviewed extensively covering various aspects of food quality and safety. ${ }^{11-13}$ However, the effects of nonthermal techniques on food chemistry and the associated degradation mechanisms have not been reviewed to date. The objective of this work is to review the effects of four of the leading nonthermal technologies, namely, high-pressure processing, pulse electric fields, ultrasound, and cold plasma on biomolecules associated with food quality, focusing on lipids and proteins.

\section{HIGH-PRESSURE PROCESSING}

High-pressure processing (HPP) is a method of food processing where food is subjected to elevated pressures (up to $900 \mathrm{MPa}$ ). HPP is the leading nonthermal technology in terms of research to date, consumer and regulatory acceptance, and industrial adoption with a wide range of food products on the global market. HPP technology has been reviewed extensively highlighting the range of applications it can offer in the food industry, assessed alone or in combination with conventional techniques. ${ }^{10,14-16} \mathrm{HPP}$ is an efficient nonthermal technology to inactivate a wide variety of pathogenic and spoilage vegetative cells, yeasts, mold, spores, and viruses associated with food products. ${ }^{17,18}$ Intrinsic food parameters governing process efficacy include water activity, $\mathrm{pH}$, and composition of food such as fats and oils. ${ }^{19}$ It is known that compression increases the temperature of the food by approximately $3{ }^{\circ} \mathrm{C} / 100 \mathrm{MPa}^{4}$ and potentially up to $8.7^{\circ} \mathrm{C} /$ $100 \mathrm{MPa}$ if the samples have high levels of fats and oils. ${ }^{20}$ The rapid increase in temperature during compression and subsequent cooling upon decompression is a unique benefit of high pressure-based technologies to reduce product thermal exposure during treatment. ${ }^{21}$

Pressure can affect the physical properties of the food matrix such as the superficial tension, density, viscosity, dipolar moment, dielectric constant, and thermal properties as well as equilibrium processes including ionization, dissociation of weak acids, and acid-base equilibrium. ${ }^{22}$ Moreover, high pressures can impact the rate of these reactions by delaying or accelerating them. In addition, HPP can modify the $\mathrm{pH}$ of the environment as it enhances the formation of ions from ionizable substances. A change in $\mathrm{pH}$ can affect protein denaturation, growth of microorganisms and the kinetics of chemical reactions. ${ }^{22}$ Even if the temperatures applied are considered as low, high pressure processing technology can affect various nutrients and bioactive molecules. For example, high-weight molecules such as proteins are formed by van der Waals forces and hydrogen and hydrostatic bonds which are weak, which can be affected by HPP. However, lower molecular weight molecules like vitamins are basically formed by covalent bonds and are typically sufficiently strong to withstand HPP conditions.

Lipids. One of the most common reactions associated with food is the oxidation of lipids. It results in a modification of color, flavors, functional properties, and nutritional values and may lead to the formation of toxic subproducts. ${ }^{23}$ First, a free alkyl is formed by removing a hydrogen atom from the $\alpha$ methylene group of a fatty acid. This initiation step is strongly encouraged by heat, light, or by the presence of metal ions and enzymes initially present in the food. The second step is called propagation. The free radical formed being highly reactive reacts with molecular oxygen to form a lipid peroxyl radical. This in turn can react with other fatty acids and generate hydroperoxide and further free radicals. Finally, this new free radical can reinitiate this process with other fatty acids. This chain reaction mechanism stops when two free fatty acids radicals react and create a nonradical, which can happen after 10-100 cycles. The termination step can also occur under the presence of antioxidant molecules (vitamin E, vitamin C, catalase, etc.) which can neutralize free radicals. ${ }^{24,25}$ Lipid oxidation is commonly measured using the TBARs method (Thiobarbituric Acid Reactive Substances), expressed in milligrams of malonaldehyde (MDA) per kilogram of sample. ${ }^{26}$ According to Connell, ${ }^{27}$ TBAR values of $1-2 \mathrm{mg} \mathrm{MDA} / \mathrm{kg}$ sample is the range of acceptability of odor/taste in fish.

The effects of high pressure on lipid oxidation have been investigated. ${ }^{28}$ High pressure should not initiate lipid oxidation, as the heterolytic cleavage to form the free radical is not favored by increases in pressure. However, the formation of covalent bounds during the propagation steps could be encouraged by pressure. Cheftel ${ }^{29}$ observed that at values above $350 \mathrm{MPa}$, and sarcoplasmic and myofibrilar proteins were denatured and myoglobin and oxymyoglobin converted to the denatured ferric form. As a consequence of these transformations, lipid oxidation was catalyzed. Orlien et al. $^{30}$ found that lipid oxidation levels depend more on the applied pressure than on the processing time and suggested that lipid oxidation is due to damage of the cell membrane which could lead to the release of free radicals or their precursors. Bolumar et al. ${ }^{31}$ applied a range of pressures for different treatment times and temperatures $\left(5,25\right.$, and $\left.40{ }^{\circ} \mathrm{C}\right)$ and observed that increasing these parameters raised the production of free radicals, thus encouraging lipid oxidation which may be due to synergistic effects of high pressure and temperature. In addition, they established thresholds for radical formation of $400 \mathrm{MPa}$ at 25 ${ }^{\circ} \mathrm{C}$ and at $500 \mathrm{MPa}$ at $5{ }^{\circ} \mathrm{C}$. Bolumar et al. ${ }^{32}$ suggested that HPP induced the formation of free radicals either by an ironcatalyzed Fenton's reaction mechanism or by the formation of protein-derived radicals. Reddy et al. ${ }^{33}$ applied 300 and 600 MPa over 5 and $10 \mathrm{~min}$ on raw chevon samples followed by storage at $4{ }^{\circ} \mathrm{C}$ for a month and reported a significant increase of lipid oxidation at $600 \mathrm{MPa}$ during the storage period. In a similar study, Wang et al. ${ }^{34}$ stored yak fat at 4 and $15{ }^{\circ} \mathrm{C}$ during 20 days after being HHP treated at 0.1, 100, 200, 400, and 600 $\mathrm{MPa}$. Lipid oxidation was observed to increase with a rise in pressure, storage temperature, and treatment time. Indeed, the TBARS values obtained were much higher at 400 and $600 \mathrm{MPa}$ compared with $200 \mathrm{MPa}$, revealing higher rates of lipid oxidation. These results match with the findings of the researchers cited previously, suggesting that lipid oxidation is encouraged after a pressure of 300-400 MPa. These results also agree with the Kaur et al. ${ }^{35}$ study on black tiger shrimps, where a significant increase of lipid oxidation was observed after high-pressure treatments; however, the MDA values remained acceptable for treatments above $300 \mathrm{MPa}$. Fuentes et al. ${ }^{36}$ studied the influence of intramuscular fat content on lipid oxidation after high pressure treatment. They applied $600 \mathrm{MPa}$ on two different parts of a dry-cured ham, namely the flank (lower fat content) and the hip (higher fat content), under subsequent storage at $2{ }^{\circ} \mathrm{C}$ over 120 days. The TBARs values obtained were higher for the samples analyzed immediately after treatment in the flank samples. This could be due to the fact that most of the fat content in the flank samples were unsaturated which are more reactive and easier to oxidize. However, at the end of the storage period, the hip samples were more susceptible to oxidization as the lipid concentration was higher. Conversely, several studies report no significant effects 
of HPP on lipid oxidation, for example, a storage study of 30 days on dried fermented sausages after different pressure treatments. ${ }^{37}$ Similarly, Chouhan et al. ${ }^{38}$ did not detect any significant effects of pressure on lipid oxidation immediately after applying 250 and $350 \mathrm{MPa}$ for $10 \mathrm{~min}$ with hilsa fish (Tenualosa ilisha) but noted an increase of lipid oxidation during storage. No alteration was observed on the lipid compounds or fatty acids composition of cow milk after highpressure treatments from 250 to $900 \mathrm{MPa}{ }^{39} \mathrm{~A}$ decrease of TBARs values were observed for treatments of $10 \mathrm{~min}$ at 300 $\mathrm{MPa}$ at 5 and $40{ }^{\circ} \mathrm{C}$ on salmon fillets. ${ }^{40}$ Moreover, Lerasle et al. $^{41}$ studied the influence of modified atmosphere packaging and high-pressure treatment. They prepared two batches of raw poultry sausage, one packaged with atmospheric air and one with a modified atmosphere composed of $50 \% \mathrm{CO}_{2}$ and $50 \%$ $\mathrm{N}_{2}$, with both pressurized at $500 \mathrm{MPa}$ for $5 \mathrm{~min}$. After treatment the samples were stored at $4{ }^{\circ} \mathrm{C}$ over 22 days. They found that lipid oxidation was significantly encouraged by the storage time and package atmosphere, but not by the pressure, with the treated samples having higher TBARs values.

Protein. Protein structure is composed of covalent and hydrophilic bonds, electrostatic, and van der Waals interactions, which make its native structure stable over a specific range of pressures and temperatures. Outside these conditions protein can be denatured. ${ }^{42}$ In addition, there is an intermediate state between the native and the denatured state which is called the molten globule state, where proteins can have specific functional properties that do not exist in any of the other two states. ${ }^{43}$

High pressure causes physical compression of the sample and consequently can modify the native structure of a protein, affecting solubility, gelation, emulsion, foaming, and water holding capacities. A reduction in the volume results in a reduction or elimination of the voids initially present in the protein structure as the protein unfolds. Thus, as globular proteins have more cavities than fibrous proteins, they are less stable when a high pressure is applied. ${ }^{44}$ In addition, the hydration effect on a protein is related to a reduction of the volume caused by electrostriction around the ionic groups, hydrogen-bonded hydration around the polar groups, and hydrophobic hydration. ${ }^{45}$ Proteins are usually denatured after applying a pressure from 100 to $1200 \mathrm{MPa}$ and the midpoint of pressure-induced transition occurs at $400-800 \mathrm{MPa}^{46}$ It is known that high temperatures can irreversibly denature proteins by transferring nonpolar hydrocarbons from the hydrophobic core toward water. However, in the case of high pressure, protein denaturation is initiated by the intrusion of water into the inner part of the protein matrix, which depends on the level of pressure applied. ${ }^{47}$ In general, below $200 \mathrm{MPa}$ there are only conformational changes on the tertiary and quaternary structure of the proteins, which are constituted by weak bonds such as hydrogen and electrostatic bonds, hydrophobic, and van der Waals interactions. These modifications are reversible after treatment and the protein can recover its native structure. However, depending on the type of protein, pressures above $300 \mathrm{MPa}$ can also affect the secondary structure and consequently cause irreversible denaturation. ${ }^{48}$ All these changes cited on protein conformational structure can initiate various reactions, causing modifications of the food quality. In addition to the pressure and treatment time, these reactions could be encouraged by temperature, $\mathrm{pH}$, ionic strength, and the presence of other components in the food matrix such as metal ions and other free radicals.
One of the most common reactions where proteins are involved is oxidation. They can be oxidized following the same chain reactions as lipids. A free radical can interact with a protein, initiating the oxidation of the latter. ${ }^{49}$ Protein oxidation can be measured by the loss of sulfhydryl groups $(\mathrm{S}-\mathrm{H})$ or by the formation of protein carbonyls. Sulfhydryl or thiol groups are very reactive and sensitive to oxidation, leading to the formation of disulfide groups. In meat for instance, these disulfide bonds can form a gel-like network, thus changing the texture of the product. ${ }^{50}$ Protein carbonyls are the common product of protein oxidation. Carbonyls (aldehydes and ketones) can be formed in proteins through four different pathways, namely, (i) direct oxidation of the side chains from lysine, threonine, arginine, and proline; (ii) nonenzymatic glycation in the presence of reducing sugars; (iii) oxidative cleavage of the peptide backbone via the $\alpha$-amidation pathway or via oxidation of glutamyl side chains; and (iv) covalent binding to nonprotein carbonylcompounds such as 4-hydroxy2-nonenal (HNE) or malondialdehyde (MDA). ${ }^{51}$ Some researchers have suggested that there could be a correlation between lipid oxidation and protein oxidation, as both elements are present in the food matrix. The oxidation of both proteins and lipids are initiated by a free radical which can be derived from a lipid or protein, causing the oxidation of other lipids or proteins. ${ }^{4,52}$ As HPP can encourage lipid oxidation, protein oxidation could also occur. For example, metmyoglobin $\mathrm{Fe}^{3+}$ is formed after a pressure treatment is applied beyond $350 \mathrm{MPa}$, as a result of the oxidation of oxymyoglobin $\mathrm{Fe}^{2+} \cdot{ }^{29}$ In addition, these researchers observed that a pressure of $200 \mathrm{MPa}$ often causes protein gelation, giving a denser structure, which leads to an increase in texture. Similar results were obtained by Reddy et al. ${ }^{33}$ after applying 300 and $600 \mathrm{MPa}$ for fresh chevon. They studied the effect of high-pressure processing on myoglobin, oxymyoglobin, and metmyoglobin, which are proteins related to the color of some food products. No changes were observed in myoglobin content. However, there was a correlation between the decrease of oxymyoglobin content and the increase of metmyoglobin content. As a result, a decoloration of the samples was more intense for higher pressures and longer times. Fuentes et al. ${ }^{53}$ applied $600 \mathrm{MPa}$ for vacuum packaged dry-cured ham using three different presentations: nonsliced vacuum-packaged dry-cured ham, dry-cured ham slices stretched out in the package, and dry-cured ham slices piled horizontally. To study the protein oxidation, they analyzed the formation of $\alpha$-aminoadipic and $\gamma$-glutamic semialdehydes (AAS and GGS, respectively) which are the results of different amino acids oxidation, such as proline, lysine, and arginine. There was a significant increase of the content of these two protein carbonyls after pressurization. Moreover, they found that lipid oxidation was highly encouraged for the treated samples which depended on the type of packaging used. Ojagh et al. ${ }^{40}$ attempted to mitigate the negative effects of high pressure by covering salmon samples with a fish gelatin-lignin film. In this experiment, they compared the formation of protein carbonyls in samples with and without the film at $300 \mathrm{MPa}$ during 5 min treatment at 5 and $40{ }^{\circ} \mathrm{C}$. They found that protein oxidation increased significantly for all the raw samples. However, the values for the samples covered by the film were significantly lower than the uncovered samples. On the other hand, Cava et al. ${ }^{54}$ found that HPP does not affect protein oxidation in dry-cured ham and dry-cured loin. However, lipid oxidation increased in the drycured lion samples and decreased for the dry-cured ham after 
this treatment. High pressure did not have any effect on the concentration of thiol groups after $600 \mathrm{MPa}$ of pressure treatment during $5 \mathrm{~min}$ on sarcoplasmic and myofibrillar proteins of brine enhanced pork semitendinosus. ${ }^{55}$ However, these values decreased during storage for sarcoplasmatic proteins but not for myofibrilla proteins, where there was a formation of $\mathrm{S}-\mathrm{H}$ groups. The explanation of this increase was based on Omana et al. ${ }^{50}$ experiments, who found an increase of $\mathrm{S}-\mathrm{H}$ groups after a pressure treatment for chicken breast meat. They suggested that this increase was related to the unfolding state of the protein, where the majority of the available sulfhydryl groups were exposed to the environment and that most of the sulfhydryl groups in the inner core were already oxidized to form disulfide bonds. However, Grossi et al. ${ }^{55}$ observed in a similar study the formation of protein carbonyl immediately after treatment for sarcoplasmic proteins, but with degradation during storage. The results suggest that high pressure (above $600 \mathrm{MPa}$ ) could accelerate the decomposition of the carbonyl group formed after oxidation.

Another common reaction of food proteins is the Maillard reaction, where an amino group reacts with a carbonyl group which is initially present in the food matrix such as reducing sugars, osones, furfural, hydroxymethylfurfural (HMF), and pyrrole derivatives. As a result the protein suffers a modification and brown polymers called melanoidins are formed. It is common in the food industry because it generates pleasant flavors and desired brown color compounds in cooked foods. However, it can lead to the production of acrylamide, a potential human carcinogen element, a result of the interaction between the amino acid asparagine and a reducing sugar. ${ }^{56}$ The Maillard reaction involves complex sequences of reactions, including condensation, cyclization, dehydration, rearrangement, isomerization, and polymerization. ${ }^{22}$ These reactions are influenced by temperature, metal ions, water activity, and $\mathrm{pH}$. Studies regarding the use of novel technologies to control the Maillard reaction are being currently carried out. ${ }^{57}$ It is known that $\mathrm{pH}$ is sensitive to pressure, as a dissociation of ionizable substances can occur under high-pressure conditions. Consequently, HPP could have an effect on the Maillard reaction. ${ }^{58}$ Martinez-Monteagudo and Saldana ${ }^{22}$ suggested that due to the complexity of the Maillard reaction, the effect of pressure should be evaluated for individual reaction steps to understand if pressure encourages or delays the overall reaction. Santos et al. ${ }^{59}$ proposed that high pressure accelerates the Maillard reaction for wine after a pressure treatment between 400 and $500 \mathrm{MPa}$ for $5 \mathrm{~min}$. The authors measured volatile compounds which are the products of the Maillard reaction, namely, 2furfural, benzaldehyde, and phenylacetaldehyde, and they found an increase of their content after treatment. On the other hand, Campus et al. ${ }^{60}$ found a reduction of several flavor compounds from the Maillard reaction after pressure treatment. However, their content increased during storage, and they suggested that the presence of their precursors such as the substrates, free amino acids can continue reacting, leading to their formation. Figure 1 schematically outlines some of the key chemistries induced due to HHP.

Finally, carboxylation is another common reaction in food chemistry which it based on the removal of the $\alpha$-carboxylic acid group of a free amino acid. The resultant amines are known as biogenic amines. The presence of these amines in food is of interest from a toxicological aspect and for their role as possible quality indicators. ${ }^{61}$ This reaction consists of two mechanisms. The first is performed by a pyridoxal phosphate

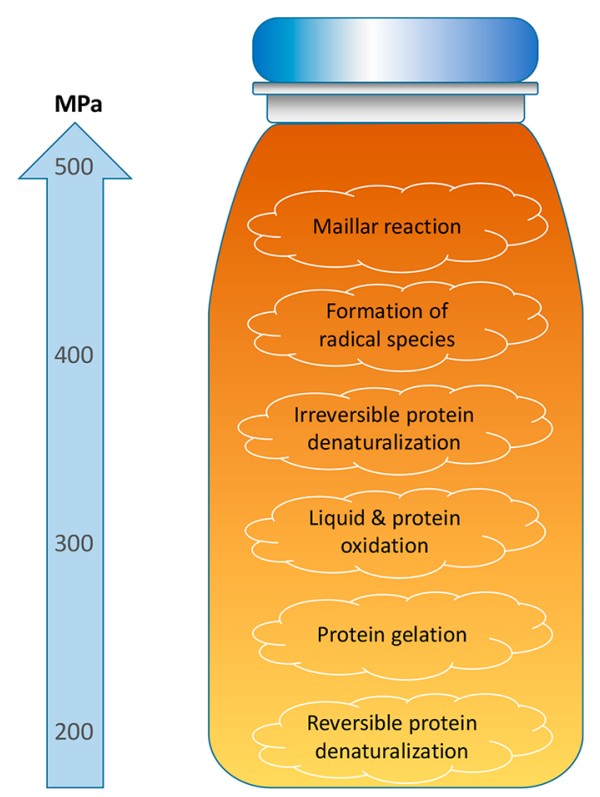

Figure 1. Key chemical changes induced due to high-pressure processing.

coenzyme, and the second is mediated by microorganisms which contain a covalently bound pyruvoyl residue on their active site. ${ }^{62}$ There are few reported studies on the effect of high pressure on biogenic amines. ${ }^{63}$ For examples, biogenic amines content was reduced on Caciotta and Pecorino cheeses when raw milk was treated at $100 \mathrm{MPa}$ before cheese production. ${ }^{64}$ Reduction of these amines after pressurization was also found for vacuum-packed trout flesh. ${ }^{65}$ Simon-Sarkadi et al. ${ }^{66}$ applied $500 \mathrm{MPa}$ to sausage finding an inhibition of the formation of two biogenic amines, namely, cadaverine and putrescine, whereas, this treatment encouraged the formation of tyramine and spermine. Spermidine and spermine were found in soya milk and they reamined stable after 200 and $300 \mathrm{MPa}$ pressurarization at 55,65 , and $75{ }^{\circ} \mathrm{C} .{ }^{67}$ However, Ruiz-Capillas et al. ${ }^{6}$ applied $400 \mathrm{MPa}$ at $30{ }^{\circ} \mathrm{C}$ for $10 \mathrm{~min}$ to frankfurters finding an increase of the biogenic amines content. Table 1 summarizes some key factors and effects of HHP on food products reported in the literature.

\section{PULSED ELECTRIC FIELDS}

Pulse electric fields (PEF) are a group of nonthermal food process technologies which have made the transition from the lab to the food industry. ${ }^{69,70}$ This technology consists of the application of short electric pulses $(1-100 \mu \mathrm{s})$ of high- and low-intensity electric fields. The food product is located between two electrodes inside a chamber, and the pulse electric field is applied over a short period. Different PEF systems have been created and optimized for efficacy and scale depending on the application and can be employed alone or in combination with thermal technology. ${ }^{71-73}$ The main two functions of this technology are inactivation of microorganisms and extraction of intracellular components. PEF is primarily based on a phenomenon called electroporation, which consists of the formation of pores on cellular membranes. As a result, there is a transitory or permanent modification of the permeability of the cell membrane and typically limited increases in the bulk temperature. The effectiveness of the electro-permeability process depends on various parameters, including, the characteristics of the PEF system (holding time, 
Table 1. Effect of High-Pressure Processing on Chemical Changes in Food Products

\begin{tabular}{|c|c|c|c|}
\hline food product & treatment & changes $^{a}$ & ref \\
\hline $\begin{array}{l}\text { beef loin and } \\
\text { chicken }\end{array}$ & $\begin{array}{l}0.1,200,400,600 \text {, and } 800 \mathrm{MPa} \text { at } \\
5,25 \text {, and } 40{ }^{\circ} \mathrm{C} \text { for } 5 \text { and } 10 \mathrm{~min}\end{array}$ & $\begin{array}{l}\text { lipid oxidation: } \\
\uparrow 400 \mathrm{MPa} \text { at } 25 \\
{ }^{\circ} \mathrm{C}, 10 \mathrm{~min} \\
\uparrow 500 \mathrm{MPa} \text { at } 5 \\
{ }^{\circ} \mathrm{C}, 10 \mathrm{~min}\end{array}$ & 31 \\
\hline fresh chevon & $\begin{array}{l}300 \text { and } 600 \mathrm{MPa} \text { at } 28^{\circ} \mathrm{C} \text { for } \\
5 \text { and } 10 \mathrm{~min}\end{array}$ & $\begin{array}{l}\text { from } 300 \mathrm{MPa} \text { at } \\
28^{\circ} \mathrm{C}, 5 \mathrm{~min} \\
\uparrow \text { lipid oxidation } \\
\uparrow \text { protein } \\
\text { oxidation }\end{array}$ & 33 \\
\hline yak & $\begin{array}{l}0.1,100,200,400 \text {, and } 600 \mathrm{MPa} \text { at } \\
4 \text { and } 15^{\circ} \mathrm{C} \text { for } 5 \text { and } 30 \mathrm{~min}\end{array}$ & $\begin{array}{l}\text { lipid oxidation: } \\
\uparrow 400 \mathrm{MPa} \text { at } 4 \\
\text { and } 15^{\circ} \mathrm{C}, 30 \\
\text { min }\end{array}$ & 34 \\
\hline $\begin{array}{l}\text { black tiger } \\
\text { shrimp }\end{array}$ & $\begin{array}{l}0.1,300,400,500 \text {, and } 600 \mathrm{MPa} \text { at } \\
27^{\circ} \mathrm{C} \text { for } 3,6,9,12 \text {, and } 15 \mathrm{~min}\end{array}$ & $\begin{array}{l}\text { lipid oxidation: } \\
\uparrow 300 \mathrm{MPa} \text { at } 27 \\
{ }^{\circ} \mathrm{C}, 12 \mathrm{~min} \\
\uparrow 400 \mathrm{MPa} \text { at } 5 \\
{ }^{\circ} \mathrm{C}, 3 \mathrm{~min}\end{array}$ & 35 \\
\hline dry-cured hams & $600 \mathrm{MPa}$ at $12{ }^{\circ} \mathrm{C}$ for $6 \mathrm{~min}$ & $\uparrow$ lipid oxidation & 36 \\
\hline $\begin{array}{l}\text { dry fermented } \\
\text { sausage }\end{array}$ & $\begin{array}{l}202 \mathrm{MPa} \text { at } 10^{\circ} \mathrm{C} \text { for } 960 \mathrm{~s} \\
260 \mathrm{MPa} \text { at } 10^{\circ} \mathrm{C} \text { for } \\
390 \text { and } 1530 \mathrm{~s} \\
400 \mathrm{MPa} \text { at } 10^{\circ} \mathrm{C} \text { for } \\
154,960 \text {, and } 1800 \mathrm{~s} \\
540 \mathrm{MPa} \text { at } 10^{\circ} \mathrm{C} \text { for } \\
390 \text { and } 1530 \mathrm{~s} \\
600 \mathrm{MPa} \text { at } 10^{\circ} \mathrm{C} \text { for } 960 \mathrm{~s}\end{array}$ & no effect & 37 \\
\hline hilsa & $\begin{array}{l}250 \text { and } 300 \mathrm{MPa} \text { at } 27^{\circ} \mathrm{C} \text { for } \\
10 \mathrm{~min}\end{array}$ & $=$ lipid oxidation & 38 \\
\hline salmon & $300 \mathrm{MPa}$ at 5 and $40^{\circ} \mathrm{C}$ for $10 \mathrm{~min}$ & $\begin{array}{l}\downarrow \text { lipid oxidation } \\
\uparrow \text { protein } \\
\text { oxidation }\end{array}$ & 40 \\
\hline dry cured ham & $600 \mathrm{MPa}$ at $12{ }^{\circ} \mathrm{C}$ for $6 \mathrm{~min}$ & $\begin{array}{l}\uparrow \text { protein } \\
\text { oxidation }\end{array}$ & 53 \\
\hline $\begin{array}{l}\text { dry-cured ham } \\
\text { and dry-cured } \\
\text { loin }\end{array}$ & $\begin{array}{l}200 \text { and } 300 \mathrm{MPa} \text { at }<14{ }^{\circ} \mathrm{C} \text { for } \\
15 \text { and } 30 \mathrm{~min}\end{array}$ & $\begin{array}{l}\uparrow \text { lipid oxidation } \\
=\text { protein } \\
\text { oxidation }\end{array}$ & 54 \\
\hline milk & $100 \mathrm{MPa}$ & $\begin{array}{l}\downarrow \text { biogenic amines } \\
\text { content }\end{array}$ & 64 \\
\hline trout flesh & $\begin{array}{l}300 \text { and } 500 \mathrm{MPa} \text { for } 10 \mathrm{~min} \text { at } \\
20{ }^{\circ} \mathrm{C}\end{array}$ & $\begin{array}{l}\downarrow \text { biogenic amines } \\
\text { content }\end{array}$ & 65 \\
\hline soya milk & $\begin{array}{l}200 \text { and } 300 \mathrm{MPa} \text { at } \\
55,65 \text {, and } 75{ }^{\circ} \mathrm{C}\end{array}$ & $=$ biogenic amines & 67 \\
\hline frankfurters & $400 \mathrm{MPa}$ at $30{ }^{\circ} \mathrm{C}$ for $10 \mathrm{~min}$ & $\uparrow$ biogenic amines & 68 \\
\hline
\end{tabular}

energy, temperature, frequency, electric strength, pulse shape, and width), the food product ( $\mathrm{pH}$ and conductivity), and the features of the bacteria cell (membrane, shape, size, and envelope structure).$^{74}$ The process can damage the membrane leading to cell inactivation as well as modification of the inner part of the cell and extraction of different substances. This process technology can effectively inactivate microorganisms which are related to the deterioration of food such as vegetative forms of bacteria, yeast, and molds. ${ }^{75}$ The application of highvoltage pulsed electric fields can lead to some electrochemical reactions, affecting the quality of specific food products. ${ }^{76}$ It is known that many chemically active species can be produced by an electric discharge in a food and also by electrode reactions with the product, such as decomposition of the chemical structure of liquids close to the electrode surfaces (electrolysis), eventually producing toxic chemical species, such as oxygen peroxide, hydroxyl radicals, or chloride ions. ${ }^{7,78}$
Arroyo et al. ${ }^{79}$ studied the lipid oxidation of fresh and frozen turkey breast treated by PEF. In this experiment, three different frequencies $(10,55$, and $110 \mathrm{~Hz})$, pulses $(100,200$, and 300 pulses) each with a pulse width of $20 \mu \mathrm{s}$, and voltages $(7.5,10$, $12.5 \mathrm{kV}$, fresh samples; 14,20 , and $25 \mathrm{kV}$, frozen samples) were tested. No significant differences were observed for the MDA values in both batches. Cortes et al. $^{80}$ noted a partial inactivation of peroxidise activity and no modification of the TBARs values after PEF treatment of horchata samples. These findings are in agreement with those of Suwandy et al., ${ }^{81}$ who concluded that PEF does not induce lipid oxidation of beef. Peanut oil was treated by PEF using a square-wave pulse generated with a pulse duration $(\tau)$ of $40 \mu$ s and pulse frequency $(f)$ of $1008 \mathrm{~Hz}^{82}$ The authors suggest that this technology could restrain the rate of the lipid oxidation reaction thus extending the shelf life of lipid rich products.

Additionally, $\mathrm{Ma}$ et al. ${ }^{83}$ found that PEF did not affect lipid oxidation immediately after treatment on three different parts of chilled and frozen-thawed cooked lamb (shoulder, rib, and loin). However, after 7 days of storage, the MDA values of the treated samples were higher than the control but still acceptable from a quality point of view (lower than $2 \mathrm{mg} \mathrm{MDA} / \mathrm{kg}$ sample). No significant changes were found in the concentration of saturated and unsaturated fatty acids after PEF treatment using bipolar square-wave pulses of $4 \mu \mathrm{s}$, at $35 \mathrm{kV} /$ $\mathrm{cm}$ field strength and a frequency of $200 \mathrm{~Hz}$ for a fruit juicesoymilk beverage during 800 and $1400 \mu$ s treatments. ${ }^{84}$ The authors reported that the treatment led to a greater reduction of the total fatty acid content. Faridnia et $\mathrm{al}^{85}$ found a significant increase in lipid oxidation both immediately after treatment and during storage for frozen-thawed beef semitendinosus muscles using process conditions of constant pulse width of $20 \mu \mathrm{s}$, electric field strength of $1.4 \mathrm{kV} / \mathrm{cm}$, constant frequency of $50 \mathrm{~Hz}$, pulse number of 1032, and total specific energy input of $250 \mathrm{~kJ} / \mathrm{kg}$. Volatiles which resulted from lipid oxidation are responsible for off-flavors and were significantly higher for the treated samples. These results could be related to the significant decrease in the concentrations of myristic acid (C14:0), palmitic acid (C16:0), palmitoleic acid (C16:1n7), oleic acid $(\mathrm{C} 18: \ln 9 \mathrm{c})$, and linoleic acid $(\mathrm{C} 18: 2 \mathrm{n} 6 \mathrm{c})$. The consequences of pulsed electric field treatment on food proteins has been reviewed by ref 86 , who suggest that PEF has less impact on the food proteins than thermal technologies. Although, they mention that PEF can inactivate some proteins and change their structure and properties. Zhao et al. ${ }^{87}$ demonstrated that PEF induces sulfhydryl-disulfide interchange reactions leading the formation of protein aggregates and a decrease in the solubility of the protein. Deactivation of peroxidase (POD) and polyphenoloxidase (PPO) for apple juice, which can cause undesirable browning reactions, were achieved using PEF. $^{88}$ Similarly, Bi et al. ${ }^{89}$ showed that the inactivation efficacy for these two enzymes with the same matrix increases as a function of electric field strength, resulting in product lightening. Protein oxidation was not detected for egg white protein solution after treatment at $200,400,600$, and $800 \mathrm{~s}$ under a constant electric field intensity of $25 \mathrm{kV} / \mathrm{cm}^{90}$ The only observed change was a slight increase in the content of sulfhydryl groups, which could be related to a gentle modification of the structure of the protein. Some effects of pulsed electric field on food products are summarized in Table 2. 


\section{Table 2. Effect of Pulsed Electric Field on Chemical Changes in Food Products}

\begin{tabular}{|c|c|c|c|}
\hline food product & treatment & changes & refs \\
\hline fresh and frozen turkey breast & $\begin{array}{l}\text { frequencies: } 10,55 \text {, and } 110 \mathrm{~Hz} \\
\text { pulses: } 100,200 \text {, and } 300 \text { pulses } \\
\text { voltages for fresh samples: } 7.5,10,12.5 \mathrm{kV} \\
\text { voltage for frozen samples: } 14,20 \text {, and } 25 \mathrm{kV} \\
\text { pulse width: } 20 \mu \mathrm{s}\end{array}$ & no lipid oxidation: & 79 \\
\hline horchata & $\begin{array}{l}\text { electric field intensity } 20-35 \mathrm{kV} / \mathrm{cm} \\
\text { treatment times } 100-475 \mu \mathrm{s}\end{array}$ & no lipid oxidation & 80 \\
\hline cold-boned beef loins and topsides & $\begin{array}{l}\text { voltage: } 10 \mathrm{kV} \\
\text { frequency: } 90 \mathrm{~Hz} \\
\text { pulse width: } 20 \mu \mathrm{s}\end{array}$ & no lipid oxidation & 81 \\
\hline peanut oil & $\begin{array}{l}\text { voltage: } 20,30,40 \text {, and } 50 \mathrm{kV} \\
\text { pulse frequency: } 1008 \mathrm{~Hz} \\
\text { pulse width: } 40 \mu \mathrm{s}\end{array}$ & restrain lipid oxidation: & 82 \\
\hline chilled and frozen-thawed cooked lamb & $\begin{array}{l}\text { electric field strength: } 1-1.4 \mathrm{kV} \mathrm{cm}^{-1} \\
\text { specific energy: } \\
88-109 \mathrm{~kJ} \mathrm{~kg}^{-1} \\
\text { pulse width: } 20 \mu \mathrm{s} \\
\text { frequency: } 90 \mathrm{~Hz} \\
\text { pulse number: } 964\end{array}$ & $\begin{array}{l}\text { lipid oxidation was found after } 7 \text { days but not just after } \\
\text { treatment }\end{array}$ & 83 \\
\hline fruit juice-soymilk beverage & $\begin{array}{l}\text { electric field strength: } 35 \mathrm{kV} / \mathrm{cm} \\
\text { pulse: } 4 \mu \mathrm{s} \\
\text { frequency: } 200 \mathrm{~Hz} \\
\text { treatment time: } 800 \text { or } 1400 \mu \mathrm{s}\end{array}$ & no effect on fatty acid content & 84 \\
\hline $\begin{array}{l}\text { frozen-thawed beef semitendinosus } \\
\text { muscles }\end{array}$ & $\begin{array}{l}\text { electric field strength: } 1.4 \mathrm{kV} / \mathrm{cm} \\
\text { specific energy input: } 250 \mathrm{~kJ} / \mathrm{kg} \\
\text { pulse width: } 20 \mu \mathrm{s} \\
\text { frequency of } 50 \mathrm{~Hz} \\
\text { pulse number: } 1032\end{array}$ & $\uparrow$ lipid oxidation & 85 \\
\hline egg white & $\begin{array}{l}\text { electric field intensity: } 25,30 \text {, and } 35 \mathrm{kV} / \mathrm{cm} \text { of } \\
\text { for } \\
\text { treatment time: } 400 \mu \mathrm{s} \\
\text { pulse repetition rate: } 200 \mathrm{~Hz} \\
\text { pulse width: } 2 \mu \mathrm{s}\end{array}$ & $\downarrow$ protein solubility & 87 \\
\hline apple juice & $\begin{array}{l}\text { flow: } 5 \mathrm{~L} / \mathrm{h} \\
\text { electric field strengths of } 15,25 \text {, and } 35 \mathrm{kV} / \mathrm{cm} \\
\text { pulse width: } 3 \mu \mathrm{s} \\
\text { energy inputs: } 8.5 \text { and } 65.5 \mathrm{~kJ} / \mathrm{kg}\end{array}$ & $\begin{array}{l}\text { deactivation of peroxidase (POD) and polyphenoloxidase } \\
(\mathrm{PPO})\end{array}$ & 88 \\
\hline egg white & $\begin{array}{l}\text { electric field intensity: } 25 \mathrm{kV} / \mathrm{cm} \\
\text { pulse repetition } \\
\text { rate: } 100 \mathrm{~Hz} \\
\text { pulse width: } 2 \mu \mathrm{s} \\
\text { treatment time: } 200,400,600 \text {, and } 800 \mu \mathrm{s}\end{array}$ & no protein oxidation & 90 \\
\hline
\end{tabular}

\section{ULTRASOUND PROCESSING}

Acoustic energy has also been investigated as a novel technology for food processing. High-frequency ultrasound (low intensity or low power) is commonly used as a nondestructive quality assessment technique. Whereas low frequency (high power) employs high intensity sound waves which can have significant impact on food properties, offering a technologically driven solution for various food processing operations including sterilization, extraction, emulsification, freezing, sonocrystallization, drying, defoaming. ${ }^{91}$ Cavitation is the main mechanism of ultrasound when applied to liquid foods using contact type systems such as ultrasound baths and probebased systems. Here, ultrasound is propagated via a series of compression and rarefaction waves through the liquid, which at sufficient power can produce cavitation. These bubbles can reach an unstable size and collapse, generating physical and chemical effects, such as localized high temperatures and pressures, radiation forces, microstreaming, shock waves, microjets, and free radicals. ${ }^{92,93}$ A second approach is to use airborne acoustic ultrasound aimed primarily at treating solid foods. Although there is a lack of knowledge regarding the mechanisms involved, the following factors can be considered: high acoustic pressures, standing waves, radiation pressure, and microstreaming. This technology has been used for drying, defoaming, and decontamination. ${ }^{94}$ As for the other technologies, antimicrobiological efficacy (log reduction), sensory parameters (color, flavor), and physicochemical characteristics (gelation, viscosity) appear to be the most studied factors following a sonication treatment. There are relatively few studies focusing on the effect of ultrasound processing on biomolecules. A summary of the modifications of this technology on different food products is summarized in Table 3.

Torkamani et al. ${ }^{95}$ studied the effect of ultrasound on different quality parameters of cheddar cheese whey including 
Table 3. Effect of Ultrasound Processing on Chemical Changes in Food Products

\begin{tabular}{|c|c|c|c|}
\hline food products & conditions & main findings & refs \\
\hline $\begin{array}{l}\text { cheddar cheese } \\
\text { whey }\end{array}$ & $\begin{array}{l}\text { frequencies between } 20 \text { to } 2000 \mathrm{kHz} \text { and specific energies between } \\
8.0 \text { to } 390 \mathrm{~kJ} / \mathrm{kg} \text { for } 10 \text { and } 30 \mathrm{~min} \text { at } 37^{\circ} \mathrm{C}\end{array}$ & $\begin{array}{l}\text { lipid oxidation occurred for both treated and untreated } \\
\text { samples }\end{array}$ & 95 \\
\hline $\begin{array}{l}\text { mackerel, cod, hake } \\
\text { and salmon }\end{array}$ & ultrasonic bath at $30 \mathrm{kHz}$ for $5,15,25,35$, and $45 \mathrm{~min}$ & $\begin{array}{l}\text { no effect of ultrasound on lipid oxidation for mackerel, cod } \\
\text { and hake }\end{array}$ & 96 \\
\hline & & slight decrease in TBARS values for treated salmon & \\
\hline pasteurized milk & probe-based system at $24 \mathrm{kHz}$ for $2.5,5,10,15$, and $20 \mathrm{~min}$ & $\begin{array}{l}\text { increase in secondary volatile products derived from lipid } \\
\text { oxidation }\end{array}$ & 97 \\
\hline $\begin{array}{l}\text { raw, thermized, and } \\
\text { pasteurized milk }\end{array}$ & $\begin{array}{l}\text { Probe-based system at } 24 \mathrm{kHz} \text { for } 2,4,8 \text {, and } 16 \mathrm{~min} \text { at } 15-25^{\circ} \mathrm{C} \text {, and } \\
0,1,2,4,6 \text {, and } 8 \text { days of storage before sampling }\end{array}$ & $\begin{array}{l}\text { volatile compounds derived from lipid oxidation increased } \\
\text { in concentration with sonication and storage time }\end{array}$ & 98 \\
\hline \multirow[t]{2}{*}{$\begin{array}{l}\text { raw and pasteurized } \\
\text { skim milk }\end{array}$} & $\begin{array}{l}\text { frequencies at } 20,400,1,000,1,600 \text { and } 2,000 \mathrm{kHz} \text { at } 4,20,45 \text {, and } 63{ }^{\circ} \mathrm{C} \\
\text { up to } 20 \mathrm{~min}\end{array}$ & $\begin{array}{l}\text { highest amount of volatiles detected at } 400 \text { and } 1,000 \mathrm{kHz} \text {, } \\
\text { where the cavitational yield and hydroxyl radical } \\
\text { production were greatest }\end{array}$ & 99 \\
\hline & & $\begin{array}{l}\text { decreasing the processing temperature and sonication time } \\
\text { can help to control the lipid oxidation }\end{array}$ & \\
\hline $\begin{array}{l}\text { refined sunflower } \\
\text { oil }\end{array}$ & ultrasound probe at $20 \mathrm{kHz}$; power at $150 \mathrm{~W}$ for $2 \mathrm{~min}$ at $20^{\circ} \mathrm{C}$ & increase of peroxide value after sonication treatment & 105 \\
\hline beef & $\begin{array}{l}\text { probe-based system at } 20 \mathrm{kHz} \text { at power intensity of } \\
2.39,6.23,11.32 \text {, and } 20.96 \mathrm{~W} \mathrm{~cm}^{-2} \text { for } 30,60,90 \text {, and } 120 \mathrm{~min}\end{array}$ & $\begin{array}{l}\text { greater lipid oxidation during ultrasound-assisted brining } \\
\text { compared to static brining protein oxidation increases } \\
\text { with high ultrasound intensities and treatment times }\end{array}$ & 106 \\
\hline soy protein isolate & probe-based system at $20 \mathrm{kHz}$ at 200, 400, and $600 \mathrm{~W}$ for 15 and $30 \mathrm{~min}$ & increase of sulfhydryl content upon sonication & 108 \\
\hline $\begin{array}{l}\text { bovine serum } \\
\text { albumin solutions }\end{array}$ & probe-based system at $20 \mathrm{~W} \mathrm{~cm}{ }^{-2}$ for 7 to $90 \mathrm{~min}$ & reduction of sulfhydryl groups & 111 \\
\hline $\begin{array}{l}\text { soy protein isolate, } \\
\text { egg white protein } \\
\text { and whey protein }\end{array}$ & ultrasonic processor at $20 \mathrm{kHz}, 4.27$ and $0.71 \mathrm{Q}$ for $20 \mathrm{~min}$ & increase of the protein surface hydrophobicity & 109 \\
\hline soy protein isolates & probe-based system at $25 \mathrm{kHz}$ at 200,400 , and $600 \mathrm{~W}$ for $15 \mathrm{~min}$ & increase of the protein surface hydrophobicity & 112 \\
\hline $\begin{array}{l}\text { black bean protein } \\
\text { isolates }\end{array}$ & probe-based system at $20 \mathrm{kHz}$ at 150,300 , and $400 \mathrm{~W}$ for 12 and $24 \mathrm{~min}$ & increase of the protein surface hydrophobicity & 113 \\
\hline
\end{tabular}

polar lipids, free and bound fatty acids, and lipid oxidation derived compounds. Lipid oxidation occurred for both untreated and treated samples notwithstanding the ultrasound treatment over time. Pedrós-Garrido et al. ${ }^{96}$ did not report any effects of ultrasound on lipid oxidation for mackerel, cod, and hake, whereas treated salmon showed a slight decrease in TBARS values. A probe-based system at $24 \mathrm{kHz}$ was used by Riener et al. ${ }^{97}$ to treat pasteurized milk for $2.5,5,10,15$, and 20 min. Secondary volatile products derived from lipid oxidation including carbonyl compounds, pentanal, hexanal, and heptanal, were detected. According to the researchers, the increase in these compounds was caused by the radical species formed under the high temperatures and pressures conditions created by cavitation. Similar results were obtained by Chouliara et al. ${ }^{98}$ for ultrasound-treated raw, thermized, and pasteurized milk. In another study, various types of milk (raw milk, pasteurized skim milk) were submitted to sound waves at different frequencies $(20,400,1000,1600$, and $2000 \mathrm{kHz})$ and temperatures $(4,20$, 45 , and $63{ }^{\circ} \mathrm{C}$ ) up to $409 \mathrm{~kJ} / \mathrm{kg}$, and the volatile compounds generated by lipid oxidation analyzed. The highest amount of volatiles was detected at 400 and $1000 \mathrm{kHz}$, at the same frequencies where the cavitational yield and the hydroxyl radical production were the greatest. ${ }^{99}$ It was observed that the production of radicals did not increase linearly with the acoustic frequency. The sonochemical yield depends on the number of active bubbles, the average temperature within these bubbles and the mass transfer effects. The first two parameters are themselves dependent on the acoustic power and frequency. An increase in the acoustic power raises the number of active cavitation bubbles, the size of these bubbles, and the temperature during collapse. Greater negative pressures can be reached during the rarefaction phases and greater positive pressures during the compression phases. ${ }^{100} \mathrm{An}$ increase in the frequency also raises the number of active cavitation bubbles but reduces the time for these bubbles to grow during rarefaction phases and to collapse during compression phases. ${ }^{101}$ Consequently, fewer acoustic cycles are required for bubbles to reach their active resonance size, and transient cavitation occurs at faster rates. ${ }^{102}$ As the maximum potential energy of the bubble is reached at its maximum size, at high frequencies the collapse is occurring with low energy. However, a greater number of active bubbles facilitates a high production of free radical species. Moreover, the effects of mass transfer during cavitation should be taken into account. During the rarefaction phase the pressure inside the bubble decreases, inducing evaporation of the solutes from the bubble/liquid interface, thus increasing the amount of water vapor. During the compression phase, the pressure inside the bubble increases, inducing condensation at the bubble wall, thus reducing the amount of water vapor. The shorter the acoustic cycle, the lower the amount of water vapor within the cavitation bubble. ${ }^{103}$ Hence, in the case of high frequencies, the amount of evaporated water decreases. This could explain the reduction in hydroxyl radical generation at the higher frequencies. It has also been demonstrated by the authors that low temperatures and sonication times help to reduce the volatiles compounds derived from lipid oxidation. This underlines the role of temperatures in the production of hydroxyl radicals, as the dissociation of water into ${ }^{\circ} \mathrm{OH}$ radicals and ${ }^{\bullet} \mathrm{H}$ atoms is encouraged by high temperatures. ${ }^{104}$ In another study on refined sunflower oil samples, free acidity, total polar compounds, peroxide value, conjugated dienes concentration, and fatty acid composition were identified and quantified before and after ultrasound treatment. The peroxide value was the only parameter with a significant difference between nonsonicated and sonicated samples. ${ }^{105}$ The oxidation of beef proteins and lipids during an ultrasound-assisted brining process has been investigated by Kang et al. ${ }^{106}$ TBARS analysis showed that ultrasound promoted greater lipid oxidation compared to static brining (0.2 MDA (mg/kg meat) at 120 
min for static brining, 1.2 MDA for the same processing time at $20.96 \mathrm{Wcm}^{-2}$ ). This result could be explained by the same consequence of cavitation described previously, namely, sonolysis. When the transient cavities undergo violent collapse, high temperatures and pressures are generated $(4000 \mathrm{~K}$ and $1000 \mathrm{~atm}$, respectively), and the dissociation of water produces hydroxyl free radicals and hydrogen atoms. In addition to temperature, ultrasound intensity plays a governing role in the production of free radical species. Indeed, Jana and Chatterjee $^{107}$ found a linear correlation between ultrasound intensity and the generation of ${ }^{\bullet} \mathrm{OH}$ radicals, up to a threshold of $3.5 \mathrm{~W} \mathrm{~cm}^{-2}$, which is likely due to saturation with cavitation bubbles. These free radicals could be responsible for lipid oxidation.

Besides lipid oxidation, protein reactions upon sonication treatment have also been studied. In a study on pea protein, a rise in sulfhydryl groups was observed after ultrasonic treatment. The results reported by $\mathrm{Hu}$ et al. ${ }^{108}$ on soy protein isolate are similar. The increase of $\mathrm{SH}$ groups content could be related to the conformation changes of the proteins upon sonication treatment. Under the effect of acoustic cavitation, the thiol groups are more exposed as the protein unfolds; conversely, the cleavage of the disulfide bonds $S-S$ of the native proteins leads to increases in the content of $\mathrm{SH}$ groups. A few studies have shown that sonication does not have any effect on the content of sulfhydryl groups. ${ }^{109,110}$ However, different conclusions have been reached regarding the effect of ultrasound on the sulfhydryl group content in other studies. Indeed, the increase in carbonyl group content and decrease in sulfhydryl group content in ultrasound treated beef proteins indicate that protein oxidation increases with high ultrasound intensities and treatment times. ${ }^{106}$ Lipid oxidation has also been observed in this study, and it has been hypothesized that the products of this reaction (i.e., malondialdehyde, carbonyl compounds) can react with proteins and form carbonyl groups. Gülseren et al. ${ }^{111}$ treated bovine serum albumin solutions (BSA) with an ultrasound probe at $20 \mathrm{~W} \mathrm{~cm}^{-2}$ for 7-90 min. They observed a reduction in sulfhydryl groups by $31 \%$ after 90 min of sonication. The reactive species formed during sonication (i.e., ${ }^{\bullet} \mathrm{OH}$ and ${ }^{\bullet} \mathrm{H}$ ) cross-react and produce hydrogen peroxide $\left(\mathrm{H}_{2} \mathrm{O}_{2}\right)$ which can alter the chemical structure of the molecules. Consequently, upon a sonication treatment, the $\mathrm{SH}$ groups localized in the inner structure of the molecules are more exposed to the interface, thus are more susceptible to oxidation. This could explain the decrease of $\mathrm{SH}$ groups after sonication treatment. Protein surface hydrophobicity is another commonly analyzed parameter which is related to the stability, conformation, and functional properties of proteins. Ultrasound treatment increases the protein surface hydrophobicity, as demonstrated in several studies including, soy protein isolates, ${ }^{112}$ black bean protein isolates, ${ }^{113}$ soy protein isolate, egg white protein, and whey protein concentrate. ${ }^{109}$ The hydrophobic groups of the proteins initially localized in the interior of the molecule are exposed to the more polar surrounding environment due to the mechanical effects of cavitation. Several studies have analyzed the protein structural changes. ${ }^{106,113}$ The results point toward a common conclusion, namely, that the $\alpha$-helix content decreases as oxidation occurs (upon sonication), and the $\beta$-sheets content increases. As a consequence of the unfolding of the proteins, internal hydrophobic regions are unmasked, and sulfhydryl group content decreases as $S-S$ bonds are created. These disulfide bonds influence the functional properties of the proteins and play an important role in the gel network structure and mechanical strength. A significant reduction in particle size treated by ultrasound was reported for soy protein isolate and whey protein concentrate. ${ }^{109,114,115}$ This reduction appeared to be greater during the first minute of treatment while the particle size is bigger. Cavitation, microstreaming, and turbulent forces occurring during a sonication treatment violently agitate the aggregates, thus reducing the size distribution. Unlike in a homogeneous solution, cavitation bubbles collapse asymmetrically in the presence of solid particles. High-speed jets of liquid are expulsed from the imploded bubble toward the solid surface. This physical mechanism, called microjets, together with shockwaves can lead to pitting, erosion, and corrosion of the solid surface as well as increasing sonochemical production following a breakage of the chemical bonds within the molecule. ${ }^{116}$ Microstreaming is another consequence of cavitation which is characterized by microscopic turbulences at the surface of the solid, increasing the rate of mass transfer. ${ }^{117}$ The probability of larger particles to be subject to cavitational energy is higher than for smaller particles; therefore, the rate of the size reduction for high weight molecules is faster than for smaller molecular weight species. ${ }^{115}$ However, different behaviors were observed for egg whites proteins, ${ }^{109}$ bovine serum albumin solutions, ${ }^{111}$ and hydroxypropylmethylcellulose, ${ }^{118}$ where an increase in the particle size after ultrasound treatment was noticed. In these cases, any partial degradation could be overcome by the formation of small aggregates due to noncovalent bonds, such as electrostatic and hydrophobic interactions. This would be one consequence of the high hydrophobic index rise upon sonication.

\section{COLD ATMOSPHERIC PLASMA}

In 1928, the American scientist Irving Langmuir proposed that the electrons, ions, and neutrons in an ionized gas could be considered as a corpuscular material entrained in a fluid medium and termed this medium "plasma". ${ }^{119}$ Nowadays, the term plasma refers to a partially or wholly ionized gas composed essentially of photons, ions, and free electrons as well as atoms in a fundamental or excited state possessing a net neutral charge. A new technology coined cold atmospheric plasma has been developed for sterilizing and modifying material with application in the food, agriculture, textile, electronic, biotechnology, and medicine sectors. ${ }^{120}$ Depending on the application, different plasma sources have been built such as corona discharge, dielectric barrier discharge (DBD), microwave discharge (MD), gliding arc, and plasma jet. ${ }^{121}$ Recently, cold plasma has emerged as a nonthermal technology with potential applications for food decontamination. ${ }^{122}$ The main interest in this technology is that it can efficiently inactivate bacteria, yeasts, molds, spores, biofilms, and other hazardous microorganisms, including potential bioterrorism agents at low/ambient temperatures and at atmospheric pressure. ${ }^{123,124}$ The efficiency of the treatment depends of different parameters including the flow of the electric charge (direct or alternating), voltage, plasma source, distance between the source and the product, treatment time, packaging material, and atmosphere. Plasma can be a tool to maintain the microbial safety of fresh food products, thus increasing the self-life of the products, with limited impact on food quality. ${ }^{125}$ Besides plasma being a potential technology to ensure food safety, it is necessary to study in depth how it is affecting food quality. During cold atmospheric plasma treatment negative and positive ions, free radical molecules, electrons, UV-photons, 
nitrogen and carbon oxides, and ozone are formed depending of the gas used. ${ }^{126,127}$ The production of reactive species (Figure 2) in cold atmospheric plasma can promote hundreds

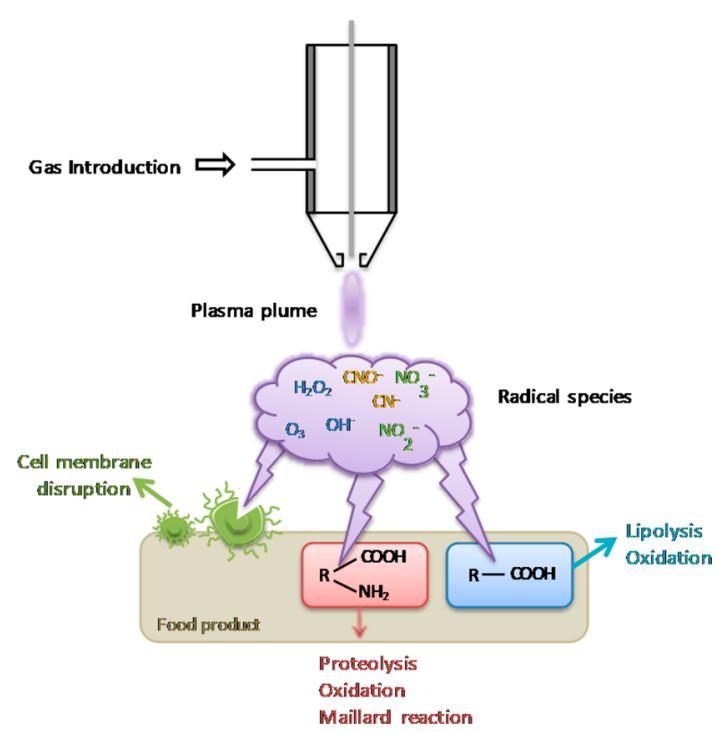

Figure 2. Cold plasma induced chemical changes.

of reactions involving several components: $\mathrm{He}, \mathrm{Ar}, \mathrm{N}, \mathrm{O}$, and $\mathrm{H}$ atoms and molecular species composed of these atoms (in ground and excited states), various atomic and molecular ion species, and electrons. ${ }^{126-128}$ Such reactions can affect the components of the food product, representing a risk for the key quality parameters of the food product. ${ }^{129,130}$

However, plasma treatment does not have the same effect on solid or liquid matrixes. In the first case, plasma is not able to penetrate significantly inside the product and is generally classified as a surface treatment, usefully where most of the microorganisms reside. Thus, the process will have limited effects on the bulk components of many solid foods. Obviously, the degree of penetration of the plasma varies depending on the food product. Whereas when a liquid food is treated, plasma can be diffused or infused in the liquid, potentially leading to more significant impacts. ${ }^{131}$

It is necessary to highlight the formation of ozone by atmospheric plasma devices. Ozone is a triatomic oxygen molecule formed by the interaction of a diatomic oxygen molecule with free oxygen radical. The breakdown of the bond $\mathrm{O}-\mathrm{O}$ to form this radical requires an energy that could be provided by the plasma system. Ozone is very reactive and unstable species, decomposing into hydroxyl, hydroperoxy, and superoxide radicals which have high oxidation potentials. The use of ozone in the food industry has been widely investigated. ${ }^{132}$ Ozone can reduce mycotoxins and microbial contamination of food products and has also been shown to be efficient in removing pesticide residues from different food matrixes. However, because of the high reactivity of ozone many reactions can occur, which can potentially affect the quality of the food products. ${ }^{133-135}$ Table 4 lists some modifications on food nutrients by cold atmospheric plasma.

The formation of radical species could suggest the hypothesis that plasma increases lipid oxidation. Wheat flour was treated by atmospheric plasma for 1 and $2 \mathrm{~min}$ at 15 and $20 \mathrm{kV}$ by Bahrami et al., ${ }^{136}$ who analyzed the level of lipid oxidation by measuring the hydroperoxides and volatile compounds produced after plasma treatment and found a significant increase of their content for all the treated samples. The difference was greater for longer treatment times and higher voltages. Moreover, they found an important reduction in the fatty acid profile, particularly linoleic acid which is an essential fatty acid for humans, with a complete reduction after $120 \mathrm{~s}$ of treatment at $20 \mathrm{kV}$. Thirumdas et al. ${ }^{123}$ observed an increase of $20 \%$ of peroxides content for plasma treated peanuts and walnuts at $60 \mathrm{kV}$, which can lead to the oxidation of lipids. Joshi et al. ${ }^{137}$ demonstrated that plasma encourages lipid oxidation

\section{Table 4. Effect of Cold Atmospheric Plasma on Chemical Changes in Food Products}

\begin{tabular}{|c|c|c|c|c|}
\hline food product & plasma source & treatment & changes & ref \\
\hline wheat flour & - & $\begin{array}{l}\text { frequency: } 9 \mathrm{kHz} \\
\text { power } 40 \mathrm{~W} \text { and voltage } 15 \mathrm{~V} \\
\text { power } 90 \mathrm{~W} \text { and voltage: } 20 \mathrm{~V} \\
\text { time: } 1 \text { and } 2 \text { min }\end{array}$ & $\begin{array}{l}\uparrow \text { lipid oxidation } \\
\text { fatty acid degradation }\end{array}$ & 136 \\
\hline walnuts and peanuts & . & $\begin{array}{l}\text { frequency: } 13.56 \mathrm{MHz} \\
\text { pressure: } 0.5 \mathrm{mbar} \\
\text { power: } 40,50,60 \mathrm{~W} \\
\text { time: } 5,10 \text { and } 15 \mathrm{~min}\end{array}$ & $\uparrow$ lipid oxidation & 123 \\
\hline raw milk & corona discharge & $\begin{array}{l}\text { power: } 9 \mathrm{kV} \\
\text { current: } 90 \mathrm{~mA} \\
\text { time: } 3,6,9,12,15 \text {, or } 20 \mathrm{~min}\end{array}$ & $\begin{array}{l}\uparrow \text { lipid oxidation } \\
=\text { fatty acids content }\end{array}$ & 138 \\
\hline vegetable oil & radio-frequency driven plasma jet & $\begin{array}{l}\text { power: } 25 \mathrm{kV} \\
\text { radio frequency power: } 13.56 \mathrm{MHz} \\
\text { gas flow: } 2 \mathrm{sl} / \mathrm{m} \\
\text { time: } 2 \mathrm{~min}\end{array}$ & $\uparrow$ lipid oxidation & 139 \\
\hline fish oil & dielectric barrier discharge and plasma jet & $\begin{array}{l}\text { voltage: } 6 \mathrm{kV} \\
\text { current: } 128 \mathrm{~mA} \\
\text { gas flow: } 2 \mathrm{sl} / \mathrm{m} \\
\text { time: } 60 \mathrm{~min}\end{array}$ & $\uparrow$ lipid oxidation & 140 \\
\hline beef jerky & radio frequency driven atmospheric plasma unit & $\begin{array}{l}\text { flow rate: } 20000 \mathrm{sccm} \\
\text { power: } 200 \mathrm{~W} \\
\text { time: } 0-10 \mathrm{~min}\end{array}$ & $=$ fatty acid composition & 142 \\
\hline
\end{tabular}


on the cellular membrane of Escherichia coli using a dielectric barrier discharge (DBD) system. From these studies, it can be concluded that the longer the treatment time the higher the radical species concentration resulting in higher levels of lipid oxidation and more pronounced impacts on food quality. In another study, a corona discharge plasma system was used for milk samples at intervals of $0,3,6,9,12,15$, and 20 min. ${ }^{138}$ The researchers did not notice noteworthy differences in the fatty acid profile among all the samples. They suggested that long chain fatty acids such as C18:00 could suffer a hydrolysis process, as their content was slightly reduced after treatment, while C10:00 and C12:00 showed a low increase. However, a significant increase was observed for the volatile compounds content, which could be related to lipid oxidation. In similar studies, Van Durme et al. ${ }^{139}$ and Vandamme et al. ${ }^{140}$ used a plasma jet device and a DBD system for vegetable and fish oils, respectively, and report that plasma accelerates lipid oxidation. However, Korachi and Aslan ${ }^{141}$ did not find any evidence of lipid oxidation nor changes of the fatty acids profile on the cellular membrane of Escherichia coli and Staphylococcus aureus treated by an atmospheric plasma corona discharge device. In addition, no significant changes in the fatty acid composition of beef jerky were observed after radio frequency (rf) atmospheric pressure plasma with 5 min of treatment. ${ }^{142}$

Apart from lipids, the effect of plasma on proteins has also been studied. ${ }^{143}$ Takai et al. ${ }^{144}$ investigated the effect of a low frequency plasma jet on an aqueous solution of 14 amino acids. They noticed that these biomolecules suffered some modifications by using high-resolution mass spectroscopy. After treatment, new molecules were observed, resulting from different reactions such as oxidation, sulfonation, amidation, sulfoxidation, hydroxylation, dehydrogenation, nitration, and dimerization depending on each specific amino acid. Segat et al. $^{145}$ studied the inactivation kinetics of an alkaline phosphatase solution at different treatment times between 5 and $300 \mathrm{~s}$ and at three different voltages: 40, 50, and $60 \mathrm{kV}$ using a DBD. The inactivation of this enzyme was detected after a few seconds of treatment and it was attributed to the loss of $\alpha$-helical and $\beta$-sheet secondary structures of the protein. Tappi et al. ${ }^{146}$ found that polyphenol oxidase activity significantly decreased for apples after plasma treatment. In another study, polyphenoloxidase (PPO) and peroxidase (POD) were denaturalized by losing the $\alpha$-helical structure using a plasma jet. ${ }^{147}$ These enzymes are part of the undesirable browning reactions related to a reduction of the nutritional and sensorial quality of vegetables and fruits. In another experiment, Park et al. ${ }^{148}$ studied the effect of plasma on hemoglobin and myoglobin $(\mathrm{Mb})$ using different gases, observing that plasma treatment leads to the modification of the secondary structure of both proteins, from $\alpha$-helical to $\beta$-sheet, and a degradation of the heme group. Conversely, Alves et al. ${ }^{149}$ studied the effect of plasma on fructooligosaccharides (FOS) and found no significant changes in FOS concentrations after applying 70 $\mathrm{kV}$ using a $\mathrm{DBD}$ system. These carbohydrates are used in the food industry as sweeteners and are interesting from a health perspective point of view due to their prebiotic activity.

Cold plasma is an early stage with regards to food application and data on the induced chemistries from the array of plasma technologies and process conditions available are only emerging. A challenge here is the complexity of the "cocktail" of active species generated, the widely different time-scales over which they may act and diagnostics of the interaction with the target product. Of course it is this complexity with provides the advantages observed in terms of process efficacy and lack of apparent resistance to the approach by microbial populations. A priory area of research will be unravelling both the mechanisms of antimicrobial action along with induced chemistry for treated foods and linking them to the key reactive species generated.

\section{CONCLUSION}

Nonthermal food processing technologies have shown great promise as microbial decontamination tools, with a large body of work found in the literature. However, the effects of these novel technologies on food chemistry have not been studied deeply (see Table 5). These promising technologies can

Table 5. Effect of Novel Technologies on Chemical Changes in Food Products ${ }^{a}$

\begin{tabular}{|c|c|c|c|c|}
\hline effects & $\begin{array}{c}\text { high } \\
\text { pressure }\end{array}$ & $\begin{array}{l}\text { pulse electric } \\
\text { field }\end{array}$ & ultrasound & plasma \\
\hline \multicolumn{5}{|l|}{ Protein } \\
\hline oxidation & + & - & + & +++ \\
\hline denaturation & +++ & ++ & +++ & ++ \\
\hline aggregation & ++ & ++ & ++ & ++ \\
\hline proteolysis & + & - & + & + \\
\hline \multicolumn{5}{|l|}{ Lipids } \\
\hline oxidation & + & + & ++ & +++ \\
\hline lipolysis & ++ & ++ & - & ++ \\
\hline
\end{tabular}

damage some nutrients, such as proteins and lipids. Consequently, more research is required into the effects and mechanisms of action of each technology on food chemistry. Such insights is key to ensure that these emerging technologies are accepted by industry, regulatory agencies, and consumers alike.

\section{AUTHOR INFORMATION}

\section{Corresponding Author}

*E-mail: Brijesh.tiwari@teagasc.ie. ORCID *

Brijesh K. Tiwari: 0000-0002-4834-6831

Funding

The work on this paper is supported by project that has received funding from the European Union's Horizon 2020 Spreading Excellence and Widening Participation programme under Grant Agreement No. 692276.

\section{Notes}

The authors declare no competing financial interest.

\section{REFERENCES}

(1) Sakr, M.; Liu, S. A comprehensive review on applications of ohmic heating (OH). Renewable Sustainable Energy Rev. 2014, 39, 262-269.

(2) Ramaswamy, H. S.; Marcotte, M.; Sastry, S.; Abdelrahim, K. Ohmic Heating in Food Processing; CRC Press, 2014.

(3) Pereira, R. N.; Vicente, A. A. Environmental impact of novel thermal and non-thermal technologies in food processing. Food Res. Int. 2010, 43, 1936-1943.

(4) Butz, P.; Tauscher, B. Emerging technologies: chemical aspects. Food Res. Int. 2002, 35 (2-3), 279-284. 
(5) Awuah, G. B.; Ramaswamy, H. S.; Economides, A. Thermal processing and quality: Principles and overview. Chem. Eng. Process. 2007, 46 (6), 584-602.

(6) Knorr, D.; Froehling, A.; Jaeger, H.; Reineke, K.; Schlueter, O.; Schoessler, K.; Doyle, M. P.; Klaenhammer, T. R. Emerging technologies in food processing. Annu. Rev. Food Sci. Technol. 2011, 2, 203-235.

(7) Jermann, C.; Koutchma, T.; Margas, E.; Leadley, C.; Ros-Polski, V. Mapping trends in novel and emerging food processing technologies around the world. Innovative Food Sci. Emerging Technol. 2015, 31, 14-27.

(8) Cullen, P. J.; Lalor, J.; Scally, L.; Boehm, D.; Milosavljević, V.; Bourke, P.; Keener, K. Translation of plasma technology from the lab to the food industry. Plasma Processes Polym. 2018, 15, 1700085.

(9) Gamboa-Santos, J.; Montilla, A.; Cárcel, J. A.; Villamiel, M.; Garcia-Perez, J. V. Air-borne ultrasound application in the convective drying of strawberry. J. Food Eng. 2014, 128, 132-139.

(10) Reineke, K.; Doehner, I.; Baier, D.; Mathys, A.; Knorr, D. The different pathways of spore germination and inactivation of Bacillus subtilis under high pressure and elevated temperatures. Procedia Food Sci. 2011, 1, 792-799.

(11) Tokuşoğlu, Ö.; Swanson, B. G. Improving Food Quality with Novel Food Processing Technologies; CRC Press, 2014.

(12) Ling, B.; Tang, J.; Kong, F.; Mitcham, E.; Wang, S. Kinetics of food quality changes during thermal processing: a review. Food Bioprocess Technol. 2015, 8, 343-358.

(13) Pinela, J.; Ferreira, I. C. Nonthermal physical technologies to decontaminate and extend the shelf-life of fruits and vegetables: Trends aiming at quality and safety. Crit. Rev. Food Sci. Nutr. 2017, 57 (10), 2095-2111.

(14) Balasubramaniam, V.; Martínez-Monteagudo, S. I.; Gupta, R. Principles and application of high pressure-based technologies in the food industry. Annu. Rev. Food Sci. Technol. 2015, 6, 435-462.

(15) Barba, F. J.; Terefe, N. S.; Buckow, R.; Knorr, D.; Orlien, V. New opportunities and perspectives of high pressure treatment to improve health and safety attributes of foods. A review. Food Res. Int. 2015, 77, 725-742.

(16) Huang, H.-W.; Wu, S.-J.; Lu, J.-K.; Shyu, Y.-T.; Wang, C.-Y. Current status and future trends of high-pressure processing in food industry. Food Control 2017, 72, 1-8.

(17) Daryaei, H.; Yousef, A. E.; Balasubramaniam, V. Microbiological Aspects of High-Pressure Processing of Food: Inactivation of Microbial Vegetative Cells and Spores. In High Pressure Processing of Food; Springer, 2016; pp 271-294.

(18) Shearer, A.; Kniel, K.; Chen, H.; Hoover, D. High-Pressure Effects on Viruses. In High Pressure Processing of Food; Springer, 2016; pp 295-315.

(19) Georget, E.; Sevenich, R; Reineke, K.; Mathys, A.; Heinz, V.; Callanan, M.; Rauh, C.; Knorr, D. Inactivation of microorganisms by high isostatic pressure processing in complex matrices: A review. Innovative Food Sci. Emerging Technol. 2015, 27, 1-14.

(20) Rasanayagam, V.; Balasubramaniam, V. M.; Ting, E.; Sizer, C. E.; Bush, C.; Anderson, C. Compression heating of selected fatty food materials during high-pressure processing. J. Food Sci. 2003, 68 (1), 254-259.

(21) Martínez-Monteagudo, S. I.; Balasubramaniam, V., Fundamentals and Applications of High-Pressure Processing Technology. In High Pressure Processing of Food; Springer, 2016; pp 3-17.

(22) Martinez-Monteagudo, S. I.; Saldana, M. D. A. Chemical Reactions in Food Systems at High Hydrostatic Pressure. Food Eng. Rev. 2014, 6 (4), 105-127.

(23) Schaich, K. Lipid oxidation: theoretical aspects. In Bailey's Industrial Oil and Fat Products; Wiley, 2005.

(24) Erickson, M. C. Lipid oxidation of muscle foods. In Food Lipids: Chemistry, Nutrition, and Biotechnology, 2nd ed.; M. Dekker, 2002.

(25) Min, D. B.; Boff, J. M. Lipid oxidation of edible oil. Food Lipids 2002, Food Science and Technology, Vol. 117 (CRC Press), 335-364.
(26) Ghani, M. A.; Barril, C.; Bedgood, D. R.; Prenzler, P. D. Measurement of antioxidant activity with the thiobarbituric acid reactive substances assay. Food Chem. 2017, 230, 195-207.

(27) Connell, J. Methods of assessing and selecting for quality. In Control of Fish Quality; Fishing News, 1990.

(28) Medina-Meza, L. G.; Barnaba, C.; Barbosa-Canovas, G. V. Effects of high pressure processing on lipid oxidation: A review. Innovative Food Sci. Emerging Technol. 2014, 22, 1-10.

(29) Cheftel, J. C. Review: High-pressure, microbial inactivation and food preservation. Food Sci. Technol. Int. 1995, 1 (2-3), 75-90.

(30) Orlien, V.; Hansen, E.; Skibsted, L. H. Lipid oxidation in highpressure processed chicken breast muscle during chill storage: critical working pressure in relation to oxidation mechanism. Eur. Food Res. Technol. 2000, 211 (2), 99-104.

(31) Bolumar, T.; Skibsted, L. H.; Orlien, V. Kinetics of the formation of radicals in meat during high pressure processing. Food Chem. 2012, 134 (4), 2114-2120.

(32) Bolumar, T.; Andersen, M. L.; Orlien, V. Mechanisms of radical formation in beef and chicken meat during high pressure processing evaluated by electron spin resonance detection and the addition of antioxidants. Food Chem. 2014, 150, 422-428.

(33) Reddy, K. J.; Jayathilakan, K.; Chauhan, O. P.; Pandey, M. C.; Radhakrishna, K. Effect of High-Pressure Processing on PhysicoChemical and Microbial Quality Characteristics of Chevon (Capra aegagrus hircus). Food Bioprocess Technol. 2015, 8 (12), 2347-2358.

(34) Wang, Q.; Zhao, X.; Ren, Y. R.; Fan, E. G.; Chang, H. J.; Wu, H. B. Effects of high pressure treatment and temperature on lipid oxidation and fatty acid composition of yak (Poephagus grunniens) body fat. Meat Sci. 2013, 94 (4), 489-494.

(35) Kaur, B. P.; Rao, P. S.; Nema, P. K. Effect of hydrostatic pressure and holding time on physicochemical quality and microbial inactivation kinetics of black tiger shrimp (Penaeus monodon). Innovative Food Sci. Emerging Technol. 2016, 33, 47-55.

(36) Fuentes, V.; Utrera, M.; Estevez, M.; Ventanas, J.; Ventanas, S. Impact of high pressure treatment and intramuscular fat content on colour changes and protein and lipid oxidation in sliced and vacuumpackaged Iberian dry-cured ham. Meat Sci. 2014, 97 (4), 468-474.

(37) Alfaia, A.; Alfaia, C. M.; Patarata, L.; Fernandes, M. J.; Fernandes, M. H.; Elias, M.; Ribeiro, M. H.; Fraqueza, M. J. Binomial effects of high isostatic pressure and time on the microbiological, sensory characteristics and lipid composition stability of vacuum packed dry fermented sausages "chourico". Innovative Food Sci. Emerging Technol. 2015, 32, 37-44.

(38) Chouhan, A.; Kaur, B. P.; Rao, P. S. Effect of high pressure processing and thermal treatment on quality of hilsa (Tenualosa ilisha) fillets during refrigerated storage. Innovative Food Sci. Emerging Technol. 2015, 29, 151-160.

(39) Rodriguez-Alcala, L. M.; Castro-Gomez, P.; Felipe, X.; Noriega, L.; Fontecha, J. Effect of processing of cow milk by high pressures under conditions up to $900 \mathrm{MPa}$ on the composition of neutral, polar lipids and fatty acids. Lwt-Food Science and Technology 2015, 62 (1), 265-270.

(40) Ojagh, S. M.; Nunez-Flores, R.; Lopez-Caballero, M. E.; Montero, M. P.; Gomez-Guillen, M. C. Lessening of high-pressureinduced changes in Atlantic salmon muscle by the combined use of a fish gelatin-lignin film. Food Chem. 2011, 125 (2), 595-606.

(41) Lerasle, M.; Federighi, M.; Simonin, H.; Anthoine, V.; Reze, S.; Cheret, R.; Guillou, S. Combined use of modified atmosphere packaging and high pressure to extend the shelf-life of raw poultry sausage. Innovative Food Sci. Emerging Technol. 2014, 23, 54-60.

(42) Smeller, L. Pressure-temperature phase diagrams of biomolecules. Biochim. Biophys. Acta, Protein Struct. Mol. Enzymol. 2002, 1595 (1-2), 11-29.

(43) Elms, P. J.; Chodera, J. D.; Bustamante, C.; Marqusee, S. The molten globule state is unusually deformable under mechanical force. Proc. Natl. Acad. Sci. U. S. A. 2012, 109 (10), 3796-3801.

(44) Damodaran, S. Amino Acids, Peptides, and Proteins; CRC Press: Boca Raton, FL, 2008; Vol. 4. 
(45) Gekko, K.; Hasegawa, Y. COMPRESSIBILITY STRUCTURE RELATIONSHIP OF GLOBULAR-PROTEINS. Biochemistry 1986, 25 (21), 6563-6571.

(46) Heremans, K. HIGH-PRESSURE EFFECTS ON PROTEINS AND OTHER BIOMOLECULES. Annu. Rev. Biophys. Bioeng. 1982, 11, 1-21.

(47) Knorr, D.; Heinz, V.; Buckow, R. High pressure application for food biopolymers. Biochim. Biophys. Acta, Proteins Proteomics 2006, 1764 (3), 619-631.

(48) Oey, I. Effects of High Pressure on Enzymes. In High Pressure Processing of Food; Springer, 2016; pp 391-431.

(49) Lund, M. N.; Heinonen, M.; Baron, C. P.; Estevez, M. Protein oxidation in muscle foods: A review. Mol. Nutr. Food Res. 2011, 55 (1), $83-95$.

(50) Omana, D. A.; Plastow, G.; Betti, M. The use of beta-glucan as a partial salt replacer in high pressure processed chicken breast meat. Food Chem. 2011, 129 (3), 768-776.

(51) Estevez, M. Protein carbonyls in meat systems: A review. Meat Sci. 2011, 89 (3), 259-279.

(52) Guyon, C.; Meynier, A.; de Lamballerie, M. Protein and lipid oxidation in meat: A review with emphasis on high-pressure treatments. Trends Food Sci. Technol. 2016, 50, 131-143.

(53) Fuentes, V.; Ventanas, J.; Morcuende, D.; Estevez, M.; Ventanas, S. Lipid and protein oxidation and sensory properties of vacuumpackaged dry-cured ham subjected to high hydrostatic pressure. Meat Sci. 2010, 85 (3), 506-514.

(54) Cava, R.; Ladero, L.; Gonzalez, S.; Carrasco, A.; Ramirez, M. R. Effect of pressure and holding time on colour, protein and lipid oxidation of sliced dry-cured Iberian ham and loin during refrigerated storage. Innovative Food Sci. Emerging Technol. 2009, 10 (1), 76-81.

(55) Grossi, A.; Bolumar, T.; Soltoft-Jensen, J.; Orlien, V. High pressure treatment of brine enhanced pork semitendinosus: Effect on microbial stability, drip loss, lipid and protein oxidation, and sensory properties. Innovative Food Sci. Emerging Technol. 2014, 22, 11-21.

(56) Poulsen, M. W.; Hedegaard, R. V.; Andersen, J. M.; de Courten, B.; Bugel, S.; Nielsen, J.; Skibsted, L. H.; Dragsted, L. O. Advanced glycation endproducts in food and their effects on health. Food Chem. Toxicol. 2013, 60, 10-37.

(57) Jaeger, H.; Janositz, A.; Knorr, D. The Maillard reaction and its control during food processing. The potential of emerging technologies. Pathol. Biol. 2010, 58 (3), 207-213.

(58) Hill, V. M.; Ledward, D. A.; Ames, J. M. Influence of high hydrostatic pressure and $\mathrm{pH}$ on the rate of maillard browning in a glucose-lysine system. J. Agric. Food Chem. 1996, 44 (2), 594-598.

(59) Santos, M. C.; Nunes, C.; Rocha, M. A. M.; Rodrigues, A.; Rocha, S. M.; Saraiva, J. A.; Coimbra, M. A. High pressure treatments accelerate changes in volatile composition of sulphur dioxide-free wine during bottle storage. Food Chem. 2015, 188, 406-414.

(60) Campus, M.; Flores, M.; Martinez, A.; Toldra, F. Effect of high pressure treatment on colour, microbial and chemical characteristics of dry cured loin. Meat Sci. 2008, 80 (4), 1174-1181.

(61) Ruiz-Capillas, C.; Jimenez-Colmenero, F. Biogenic amines in meat and meat products. Crit. Rev. Food Sci. Nutr. 2005, 44 (7-8), 489-599.

(62) Eitenmiller, R. R; Desouza, S. C. ENZYMATIC MECHANISMS FOR AMINE FORMATION IN FISH. ACS Symp. Ser. 1984, 262, 431-442.

(63) Naila, A.; Flint, S.; Fletcher, G.; Bremer, P.; Meerdink, G. Control of Biogenic Amines in Food-Existing and Emerging Approaches. J. Food Sci. 2010, 75 (7), R139-R150.

(64) Lanciotti, R.; Patrignani, F.; Iucci, L.; Guerzoni, M. E.; Suzzi, G.; Belletti, N.; Gardini, F. Effects of milk high pressure homogenization on biogenic amine accumulation during ripening of ovine and bovine Italian cheeses. Food Chem. 2007, 104 (2), 693-701.

(65) Matejkova, K.; Krizek, M.; Vacha, F.; Dadakova, E. Effect of high-pressure treatment on biogenic amines formation in vacuumpacked trout flesh (Oncorhynchus mykiss). Food Chem. 2013, 137 (14), 31-36.
(66) Simon-Sarkadi, L.; Pasztor-Huszar, K.; Dalmadi, I.; Kisko, G. Effect of high hydrostatic pressure processing on biogenic amine content of sausage during storage. Food Res. Int. 2012, 47 (2), 380384.

(67) Toro-Funes, N.; Bosch-Fuste, J.; Veciana-Nogues, M. T.; VidalCarou, M. C. Effect of ultra high pressure homogenization treatment on the bioactive compounds of soya milk. Food Chem. 2014, 152, $597-602$.

(68) Ruiz-Capillas, C.; Carballo, J.; Jimenez-Colmenero, F. Consequences of high-pressure processing of vacuum-packaged frankfurters on the formation of polyamines: Effect of chilled storage. Food Chem. 2007, 104 (1), 202-208.

(69) Mahnic-Kalamiza, S.; Vorobiev, E.; Miklavcic, D. Electroporation in Food Processing and Biorefinery. J. Membr. Biol. 2014, 247 (12), 1279-1304.

(70) Puertolas, E.; Alvarez, I.; Raso, J.; de Maranon, I. M. Industrial application of pulsed electric field for food pasteurization: review of its technical and commercial viability. CyTA-J. Food 2013, 11 (1), 81-88.

(71) Wu, L.; Zhao, W.; Yang, R. J.; Yan, W. X.; Sun, Q. Y. Aggregation of egg white proteins with pulsed electric fields and thermal processes. J. Sci. Food Agric. 2016, 96 (10), 3334-3341.

(72) Huang, K.; Wang, J. P. Designs of pulsed electric fields treatment chambers for liquid foods pasteurization process: A review. J. Food Eng. 2009, 95 (2), 227-239.

(73) Liu, Y. F.; Oey, I.; Bremer, P.; Carne, A.; Silcock, P. Effects of $\mathrm{pH}$, temperature and pulsed electric fields on the turbidity and protein aggregation of ovomucin-depleted egg white. Food Res. Int. 2017, 91, $161-170$.

(74) Puertolas, E.; Luengo, E.; Alvarez, I.; Raso, J.; Doyle, M. P.; Klaenhammer, T. R. Improving Mass Transfer to Soften Tissues by Pulsed Electric Fields: Fundamentals and Applications. Annu. Rev. Food Sci. Technol. 2012, 3, 263-282.

(75) Saldana, G.; Alvarez, I.; Condon, S.; Raso, J. Microbiological Aspects Related to the Feasibility of PEF Technology for Food Pasteurization. Crit. Rev. Food Sci. Nutr. 2014, 54 (11), 1415-1426.

(76) Roodenburg, B. Electrochemistry in pulsed electric field treatment chambers. In Food Preservation by Pulsed Electric Fields: From Research to Application; Elsevier, 2007; pp 94, DOI: 10.1533/ 9781845693831.1.94

(77) Matser, A.; Schuten, H.; Mastwijk, H.; Lommen, A. Toxicological aspects of preservation of food by pulsed electric fields. In Food Preservation by Pulsed Electric Fields: From Research to Application; CRC Press, 2007; pp 201-211, DOI: 10.1201/ 9781439823866.ch13

(78) Mañas, P.; Vercet, A. Effect of PEF on enzymes and food constituents. In Pulsed Electric Fields Technology for the Food Industry; Springer, 2006; pp 131-151.

(79) Arroyo, C.; Eslami, S.; Brunton, N. P.; Arimi, J. M.; Noci, F.; Lyng, J. G. An assessment of the impact of pulsed electric fields processing factors on oxidation, color, texture, and sensory attributes of turkey breast meat. Poult. Sci. 2015, 94 (5), 1088-1095.

(80) Cortes, C.; Esteve, M.; Frigola, A.; Torregrosa, F. Quality characteristics of horchata (a Spanish vegetable beverage) treated with pulsed electric fields during shelf-life. Food Chem. 2005, 91 (2), 319325.

(81) Suwandy, V.; Carne, A.; van de Ven, R.; Bekhit, A. E. A.; Hopkins, D. L. Effect of Repeated Pulsed Electric Field Treatment on the Quality of Cold-Boned Beef Loins and Topsides. Food Bioprocess Technol. 2015, 8 (6), 1218-1228.

(82) Zeng, X. A.; Han, Z.; Zi, Z. H. Effects of pulsed electric field treatments on quality of peanut oil. Food Control 2010, 21 (5), 611614.

(83) Ma, Q. L.; Hamid, N.; Oey, I.; Kantono, K.; Faridnia, F.; Yoo, M.; Farouk, M. Effect of chilled and freezing pre-treatments prior to pulsed electric field processing on volatile profile and sensory attributes of cooked lamb meats. Innovative Food Sci. Emerging Technol. 2016, 37, 359-374.

(84) Morales-de la Pena, M.; Salvia-Trujillo, L.; Rojas-Grau, M. A.; Martin-Belloso, O. Impact of high intensity pulsed electric fields or 
heat treatments on the fatty acid and mineral profiles of a fruit juicesoymilk beverage during storage. Food Control 2011, 22 (12), 19751983.

(85) Faridnia, F.; Ma, Q. L.; Bremer, P. J.; Burritt, D. J.; Hamid, N.; Oey, I. Effect of freezing as pre-treatment prior to pulsed electric field processing on quality traits of beef muscles. Innovative Food Sci. Emerging Technol. 2015, 29, 31-40.

(86) Zhao, W.; Tang, Y. L.; Lu, L. X.; Chen, X.; Li, C. Y. Review: Pulsed Electric Fields Processing of Protein-Based Foods. Food Bioprocess Technol. 2014, 7 (1), 114-125.

(87) Zhao, W.; Yang, R. J.; Tang, Y. L.; Zhang, W. B.; Hua, X. Investigation of the Protein-Protein Aggregation of Egg White Proteins under Pulsed Electric Fields. J. Agric. Food Chem. 2009, 57 (9), 3571-3577.

(88) Schilling, S.; Schmid, S.; Jaeger, H.; Ludwig, M.; Dietrich, H.; Toepfl, S.; Knorr, D.; Neidhart, S.; Schieber, A.; Carlet, R. Comparative study of pulsed electric field and thermal processing of apple juice with particular consideration of juice quality and enzyme deactivation. J. Agric. Food Chem. 2008, 56 (12), 4545-4554.

(89) Bi, X. F.; Liu, F. X.; Rao, L.; Li, J.; Liu, B. J.; Liao, X. J.; Wu, J. H. Effects of electric field strength and pulse rise time on physicochemical and sensory properties of apple juice by pulsed electric field. Innovative Food Sci. Emerging Technol. 2013, 17, 85-92.

(90) Wu, L.; Zhao, W.; Yang, R. J.; Chen, X. C. Effects of pulsed electric fields processing on stability of egg white proteins. J. Food Eng. 2014, 139, 13-18.

(91) Awad, T.; Moharram, H.; Shaltout, O.; Asker, D.; Youssef, M. Applications of ultrasound in analysis, processing and quality control of food: A review. Food Res. Int. 2012, 48 (2), 410-427.

(92) O’Brien, W. D. Ultrasound-biophysics mechanisms. Prog. Biophys. Mol. Biol. 2007, 93 (1), 212-255.

(93) Mason, T. J. High Powered Ultrasound in Physical and Chemical Processing. In New Acoustics. Selected Topics; Ranz, C., Gallego, J. A., Eds.; CSIC: Madrid, Spain, 2002.

(94) Charoux, C. M.; Ojha, K. S.; O’Donnell, C. P.; Cardoni, A.; Tiwari, B. K. Applications of airborne ultrasonic technology in the food industry. J. Food Eng. 2017, 208, 28-36.

(95) Torkamani, A. E.; Juliano, P.; Ajlouni, S.; Singh, T. K. Impact of ultrasound treatment on lipid oxidation of Cheddar cheese whey. Ultrason. Sonochem. 2014, 21 (3), 951-957.

(96) Pedrós-Garrido, S.; Condón-Abanto, S.; Beltrán, J.; Lyng, J.; Brunton, N.; Bolton, D.; Whyte, P. Assessment of high intensity ultrasound for surface decontamination of salmon (S. salar), mackerel (S. scombrus), cod (G. morhua) and hake (M. merluccius) fillets, and its impact on fish quality. Innovative Food Sci. Emerging Technol. 2017, $41,64-70$.

(97) Riener, J.; Noci, F.; Cronin, D. A.; Morgan, D. J.; Lyng, J. G. Characterisation of volatile compounds generated in milk by high intensity ultrasound. Int. Dairy J. 2009, 19 (4), 269-272.

(98) Chouliara, E.; Georgogianni, K.; Kanellopoulou, N.; Kontominas, M. Effect of ultrasonication on microbiological, chemical and sensory properties of raw, thermized and pasteurized milk. Int. Dairy J. 2010, 20 (5), 307-313.

(99) Juliano, P.; Torkamani, A. E.; Leong, T.; Kolb, V.; Watkins, P.; Ajlouni, S.; Singh, T. K. Lipid oxidation volatiles absent in milk after selected ultrasound processing. Ultrason. Sonochem. 2014, 21 (6), $2165-2175$.

(100) Kanthale, P.; Ashokkumar, M.; Grieser, F. Sonoluminescence, sonochemistry ( $\mathrm{H} 2 \mathrm{O} 2$ yield) and bubble dynamics: frequency and power effects. Ultrason. Sonochem. 2008, 15 (2), 143-150.

(101) Leighton, T. Bubble population phenomena in acoustic cavitation. Ultrason. Sonochem. 1995, 2 (2), S123-S136.

(102) Beckett, M. A.; Hua, I. Impact of ultrasonic frequency on aqueous sonoluminescence and sonochemistry. J. Phys. Chem. A 2001, 105 (15), 3796-3802.

(103) Ashokkumar, M.; Sunartio, D.; Kentish, S.; Mawson, R.; Simons, L.; Vilkhu, K.; Versteeg, C. K. Modification of food ingredients by ultrasound to improve functionality: a preliminary study on a model system. Innovative Food Sci. Emerging Technol. 2008, 9 (2), 155-160.

(104) Riesz, P.; Kondo, T. Free radical formation induced by ultrasound and its biological implications. Free Radical Biol. Med. 1992, 13 (3), 247-270.

(105) Chemat, F.; Grondin, I.; Costes, P.; Moutoussamy, L.; Sing, A. S. C.; Smadja, J. High power ultrasound effects on lipid oxidation of refined sunflower oil. Ultrason. Sonochem. 2004, 11 (5), 281-285.

(106) Kang, D.-c.; Zou, Y.-h.; Cheng, Y.-p.; Xing, L.-j.; Zhou, G.-h.; Zhang, W.-g. Effects of power ultrasound on oxidation and structure of beef proteins during curing processing. Ultrason. Sonochem. 2016, 33, 47-53.

(107) Jana, A. K.; Chatterjee, S. Estimation of hydroxyl free radicals produced by ultrasound in Fricke solution used as a chemical dosimeter. Ultrason. Sonochem. 1995, 2 (2), S87-S91.

(108) Hu, H.; Wu, J.; Li-Chan, E. C.; Zhu, L.; Zhang, F.; Xu, X.; Fan, G.; Wang, L.; Huang, X.; Pan, S. Effects of ultrasound on structural and physical properties of soy protein isolate (SPI) dispersions. Food Hydrocolloids 2013, 30 (2), 647-655.

(109) Arzeni, C.; Martínez, K.; Zema, P.; Arias, A.; Pérez, O.; Pilosof, A. Comparative study of high intensity ultrasound effects on food proteins functionality. J. Food Eng. 2012, 108 (3), 463-472.

(110) Chandrapala, J.; Zisu, B.; Palmer, M.; Kentish, S.; Ashokkumar, $M$. Effects of ultrasound on the thermal and structural characteristics of proteins in reconstituted whey protein concentrate. Ultrason. Sonochem. 2011, 18 (5), 951-957.

(111) Gülseren, I.; Güzey, D.; Bruce, B. D.; Weiss, J. Structural and functional changes in ultrasonicated bovine serum albumin solutions. Ultrason. Sonochem. 2007, 14 (2), 173-183.

(112) Chen, L.; Chen, J.; Ren, J.; Zhao, M. Effects of ultrasound pretreatment on the enzymatic hydrolysis of soy protein isolates and on the emulsifying properties of hydrolysates. J. Agric. Food Chem. 2011, 59 (6), 2600-2609.

(113) Jiang, L.; Wang, J.; Li, Y.; Wang, Z.; Liang, J.; Wang, R.; Chen, Y.; Ma, W.; Qi, B.; Zhang, M. Effects of ultrasound on the structure and physical properties of black bean protein isolates. Food Res. Int. 2014, 62, 595-601.

(114) Jambrak, A. R.; Lelas, V.; Mason, T. J.; Krešić, G.; Badanjak, M. Physical properties of ultrasound treated soy proteins. J. Food Eng. 2009, 93 (4), 386-393.

(115) Gordon, L.; Pilosof, A. M. Application of high-intensity ultrasounds to control the size of whey proteins particles. Food Biophysics 2010, 5 (3), 203-210.

(116) Lu, Y.; Riyanto, N.; Weavers, L. K. Sonolysis of synthetic sediment particles: particle characteristics affecting particle dissolution and size reduction. Ultrason. Sonochem. 2002, 9 (4), 181-188.

(117) Hagenson, L. C.; Doraiswamy, L. Comparison of the effects of ultrasound and mechanical agitation on a reacting solid-liquid system. Chem. Eng. Sci. 1998, 53 (1), 131-148.

(118) Camino, N. A.; Pérez, O. E.; Pilosof, A. M. Molecular and functional modification of hydroxypropylmethylcellulose by highintensity ultrasound. Food Hydrocolloids 2009, 23 (4), 1089-1095.

(119) Langmuir, I. Oscillations in ionized gases. Proc. Natl. Acad. Sci. U. S. A. 1928, 14 (8), 627-637.

(120) Kramer, A.; Bekeschus, S.; Matthes, R.; Bender, C.; Stope, M. B.; Napp, M.; Lademann, O.; Lademann, J.; Weltmann, K. D.; Schauer, F. Cold Physical Plasmas in the Field of Hygiene-Relevance, Significance, and Future Applications. Plasma Processes Polym. 2015, 12 (12), 1410-1422.

(121) Scholtz, V.; Pazlarova, J.; Souskova, H.; Khun, J.; Julak, J. Nonthermal plasma - A tool for decontamination and disinfection. Biotechnol. Adv. 2015, 33 (6), 1108-1119.

(122) Misra, N.; Schlüter, O.; Cullen, P. Cold Plasma in Food and Agriculture: Fundamentals and Applications. Academic Press, 2016.

(123) Thirumdas, R.; Sarangapani, C.; Annapure, U. S. Cold Plasma: A novel Non-Thermal Technology for Food Processing. Food Biophysics 2015, 10 (1), 1-11. 
(124) Liao, X.; Liu, D.; Xiang, Q.; Ahn, J.; Chen, S.; Ye, X.; Ding, T. Inactivation mechanisms of non-thermal plasma on microbes: A review. Food Control 2017, 75, 83-91.

(125) Misra, N. N.; Tiwari, B. K.; Raghavarao, K.; Cullen, P. J. Nonthermal Plasma Inactivation of Food-Borne Pathogens. Food Eng. Rev. 2011, 3 (3-4), 159-170.

(126) Lu, X.; Naidis, G. V.; Laroussi, M.; Reuter, S.; Graves, D. B.; Ostrikov, K. Reactive species in non-equilibrium atmospheric-pressure plasmas: Generation, transport, and biological effects. Phys. Rep. 2016, 630, $1-84$.

(127) Graves, D. B. The emerging role of reactive oxygen and nitrogen species in redox biology and some implications for plasma applications to medicine and biology. J. Phys. D: Appl. Phys. 2012, 45 (26), 263001.

(128) Gorbanev, Y.; Stehling, N.; O'Connell, D.; Chechik, V. Reactions of nitroxide radicals in aqueous solutions exposed to nonthermal plasma: limitations of spin trapping of the plasma induced species. Plasma Sources Sci. Technol. 2016, 25 (5), 055017.

(129) Kim, H.-J.; Jayasena, D. D.; Yong, H.I.; Jo, C. Quality of Cold Plasma Treated Foods of Animal Origin. In Cold Plasma in Food and Agriculture: Fundamentals and Applications; Elsevier, 2016; p 273.

(130) Misra, N.Quality of Cold Plasma Treated Plant Foods. In Cold Plasma in Food and Agriculture: Fundamentals and Applications; Elsevier: 2016; p 253.

(131) Surowsky, B.; Schluter, O.; Knorr, D. Interactions of NonThermal Atmospheric Pressure Plasma with Solid and Liquid Food Systems: A Review. Food Eng. Rev. 2015, 7 (2), 82-108.

(132) O’Donnell, C.; Tiwari, B. K.; Cullen, P.; Rice, R. G. Ozone in Food Processing;John Wiley \& Sons, 2012.

(133) Greene, A. K.; Guzel-Seydim, Z.; Seydim, A. C. Chemical and Physical Properties of Ozone; John Wiley and Sons: Oxford, U.K., 2012; pp 19-31.

(134) Perry, J. J.; Yousef, A. E.; Doyle, M. P.; Klaenhammer, T. R. Decontamination of Raw Foods Using Ozone-Based Sanitization Techniques. Annu. Rev. Food Sci. Technol. 2011, 2, 281-298.

(135) Glowacz, M.; Colgan, R.; Rees, D. The use of ozone to extend the shelf-life and maintain quality of fresh produce. J. Sci. Food Agric. 2015, 95 (4), 662-671.

(136) Bahrami, N.; Bayliss, D.; Chope, G.; Penson, S.; Perehinec, T.; Fisk, I. D. Cold plasma: A new technology to modify wheat flour functionality. Food Chem. 2016, 202, 247-253.

(137) Joshi, S. G.; Cooper, M.; Yost, A.; Paff, M.; Ercan, U. K.; Fridman, G.; Friedman, G.; Fridman, A.; Brooks, A. D. Nonthermal Dielectric-Barrier Discharge Plasma-Induced Inactivation Involves Oxidative DNA Damage and Membrane Lipid Peroxidation in Escherichia coli. Antimicrob. Agents Chemother. 2011, 55 (3), 10531062.

(138) Korachi, M.; Ozen, F.; Aslan, N.; Vannini, L.; Guerzoni, M. E.; Gottardi, D.; Ekinci, F. Y. Biochemical changes to milk following treatment by a novel, cold atmospheric plasma system. Int. Dairy J. 2015, 42, 64-69.

(139) Van Durme, J.; Nikiforov, A.; Vandamme, J.; Leys, C.; De Winne, A. Accelerated lipid oxidation using non-thermal plasma technology: Evaluation of volatile compounds. Food Res. Int. 2014, 62, 868-876.

(140) Vandamme, J.; Nikiforov, A.; Dujardin, K.; Leys, C.; De Cooman, L.; Van Durme, J. Critical evaluation of non-thermal plasma as an innovative accelerated lipid oxidation technique in fish oil. Food Res. Int. 2015, 72, 115-125.

(141) Korachi, M.; Aslan, N. The Effect of Atmospheric Pressure Plasma Corona Discharge on $\mathrm{pH}$, Lipid Content and DNA of Bacterial Cells. Plasma Sci. Technol. 2011, 13 (1), 99-105.

(142) Kim, J. S.; Lee, E. J.; Choi, E. H.; Kim, Y. J. Inactivation of Staphylococcus aureus on the beef jerky by radio-frequency atmospheric pressure plasma discharge treatment. Innovative Food Sci. Emerging Technol. 2014, 22, 124-130.

(143) Misra, N. N.; Pankaj, S. K.; Segat, A.; Ishikawa, K. Cold plasma interactions with enzymes in foods and model systems. Trends Food Sci. Technol. 2016, 55, 39-47.
(144) Takai, E.; Kitamura, T.; Kuwabara, J.; Ikawa, S.; Yoshizawa, S.; Shiraki, K.; Kawasaki, H.; Arakawa, R.; Kitano, K. Chemical modification of amino acids by atmospheric-pressure cold plasma in aqueous solution. J. Phys. D: Appl. Phys. 2014, 47 (28), 285403.

(145) Segat, A.; Misra, N. N.; Cullen, P. J.; Innocente, N. Effect of atmospheric pressure cold plasma (ACP) on activity and structure of alkaline phosphatase. Food Bioprod. Process. 2016, 98, 181-188.

(146) Tappi, S.; Berardinelli, A.; Ragni, L.; Rosa, M. D.; Guarnieri, A.; Rocculi, P. Atmospheric gas plasma treatment of fresh-cut apples. Innovative Food Sci. Emerging Technol. 2014, 21, 114-122.

(147) Surowsky, B.; Fischer, A.; Schlueter, O.; Knorr, D. Cold plasma effects on enzyme activity in a model food system. Innovative Food Sci. Emerging Technol. 2013, 19, 146-152.

(148) Park, J. H.; Kim, M.; Shiratani, M.; Cho, A. E.; Choi, E. H.; Attri, P. Variation in structure of proteins by adjusting reactive oxygen and nitrogen species generated from dielectric barrier discharge jet. Sci. Rep. 2016, 6, 35883.

(149) Alves Filho, E. G.; Cullen, P. J.; Frias, J. M.; Bourke, P.; Tiwari, B. K.; Brito, E. S.; Rodrigues, S.; Fernandes, F. A. N. Evaluation of plasma, high-pressure and ultrasound processing on the stability of fructooligosaccharides. Int. J. Food Sci. Technol. 2016, 51 (9), 20342040. 